Özer-Şanal, S., Akçay, A., Çiçek-Tutulmaz, M. \& Erdem, M. (2019). Application of Learning Theories in Online Instructional Environments and Materials: A Study for Developing a Set of Criteria. Bartın University Journal of Faculty of Education, 8(2), 707-732.

Bartın University Journal of Faculty of Education, 8(2), 707-732

Bartın Üniversitesi Eğitim Fakültesi Dergisi, 8(2), 707-732

buefad.bartin.edu.tr

\title{
Application of Learning Theories in Online Instructional Environments and Materials: A Study for Developing a Set of Criteria
}

\author{
Seda ÖZER ŞANAL*a ${ }^{*}$, Arif AKÇAY ${ }^{\mathrm{b}}$, Meral ÇİÇEK TUTULMAZ ${ }^{\mathrm{c}}$, Mukaddes ERDEM $^{\mathrm{d}}$
}

\begin{tabular}{l} 
Article Info \\
\hline DOI: $10.14686 /$ buefad.528904 \\
\hline Article History: \\
Received: $\quad 19.02 .2019$ \\
Accepted: $\quad 03.06 .2019$ \\
Published: $\quad 30.06 .2019$ \\
\hline Keywords: \\
Learning theory, \\
Online learning environment, \\
scale development. \\
\hline Article Type: \\
Research article \\
\end{tabular}

\begin{abstract}
The aim of this study was to develop a set of agreed criteria for the examination or formation of online instructional environments and materials from the viewpoint of learning theories. Based on the understanding that the guidance of learning theories is needed in all stages of an instructional design process from planning to implementation, this study first examined the behaviourist, cognitive, and constructivist learning theories about learning. Instructional practice examples were then examined to determine statements showing how these explanations reflect on the instructional environments or materials. The first statements revised in line with the expert opinions were turned into a 5-point Likert type scale. The opinions of the experts were received on the scale and the necessary revisions were made. Using the 70-item scale, six different open access instructional materials from the Educational Informatics Network (EBA) were examinedContent validity indices were calculated based on the opinions of 26 experts for the final scale, for which the acceptable levels of conformity were determined. At the end of the final review, a set of criteria consisting of 60 items was developed.
\end{abstract}

\section{Öğrenme Kuramlarının Çevrimiçi Öğretim Ortamlarında ve Materyallerinde Uygulanması: Bir Ölçütler Takımı Geliştirme Çalışması}

\begin{tabular}{|c|c|}
\hline Makal & gisi \\
\hline DOI: 10 & 586/buefad.528904 \\
\hline Makale & mişi: \\
\hline Geliş: & 19.02 .2019 \\
\hline Kabul: & 03.06.2019 \\
\hline Yayın: & 30.06 .2019 \\
\hline $\begin{array}{l}\text { Anahtar } \\
\text { Öğrenm } \\
\text { Çevrimi } \\
\text { Ölçek g }\end{array}$ & $\begin{array}{l}\text { limeler: } \\
\text { uramı, } \\
\text { ğrenme ortamı, } \\
\text { irme. }\end{array}$ \\
\hline $\begin{array}{l}\text { Makale } \\
\text { Araştırn }\end{array}$ & akalesi \\
\hline
\end{tabular}

Öz

$\mathrm{Bu}$ çalışma, çevrimiçi öğretim ortamlarının ve materyallerinin öğrenme kuramları perspektifinden incelenmesini ya da oluşturulmasını olanaklı kılacak, üzerinde uzlaşılmış bir ölçütler takımı oluşturmak üzere gerçekleştirilmiştir. Bir öğretim tasarım sürecinin, planlanmasından uygulanıp geliştirilmesine kadar geçen tüm aşamalarında öğrenme kuramlarının rehberliğine gereksinim olduğu anlayıșıyla gerçekleştirilen çalışmada; öncelikle davranışçı, bilişsel ve yapılandırmacı öğrenme kuramlarının öğrenmeye ilişkin açıklamaları incelenmiştir. Daha sonra, bu açıklamaların öğretim ortam ya da materyallerinde nasıl karşılık bulacağı, öğretimsel uygulamalar türünden belirlenmeye çalışılmıştır. Uzman görüşleri doğrultusunda gözden geçirilen bu ilk ifadeler, 5'li likert tipinde bir ölçek formunda düzenlenmiştir. Ölçek yeniden uzman görüşüne sunulmuş ve alınan görüşler doğrultusunda düzenlenmiştir. 70 maddeden oluşan yeni form kullanılarak; EBA(Eğitim Bilișim A ğı)'dan herkese açık 6 farklı öğretim materyali incelenmiştir.

*Corresponding Author: sedaozer@firat.edu.tr

${ }^{a}$ Res. Assist., Firat University, Elazığ/Turkey, https://orcid.org/0000-0002-6260-9212

b Res. Assist., Kastamonu University, Kastamonu/Turkey, https://orcid.org/0000-0001-9103-9469

${ }^{c}$ Graduate Student, Hacettepe University, Ankara/Turkey, https://orcid.org/0000-0001-8416-8625

d Prof. Dr., Hacettepe University, Ankara/Turkey, https://orcid.org/0000-0002-8724-3923 


\section{Introduction}

Instructional design is the systematic development process of instructional practices paving the way for qualified learning using learning and education theories. Education cannot take place randomly but requires wellorganized processes (Seels and Glasgow, 1990: 3-4). Thus, organizing instructional activities that lead to desirable results is closely associated with the extent to which the explanations on what learning is and how it takes place are taken into consideration.

Within this framework, the present study was conducted considering the question of how to transform learning theories into instructional practices. In the study were addressed online instructional environments or materials according to their content and interaction dynamics.

\section{Behaviourist Learning Theories}

According to behaviourist learning theories, learning is the production of an appropriate reaction to a specific stimulant (Ertmer and Newby, 2013). Learning occurs when a change is made in the form or frequency of an observable behaviour (Schunk, 2014). Behaviourist theories are not interested in students' existing information structures or cognitive processes. They instead focus on the production of observable behaviours which are openly and clearly specified in the education targets. In this respect, in behaviourist learning, it is essential to clearly describe and plan all phases of a process like a machine so that education is completed successfully and target behaviours are acquired for the fulfilment of the targets (Mechlova and Malcik, 2012; Reed, 2012; Tennyson, 2010).

In the behaviourist approach, learning is triggered by an observable and reliable connection between the stimulant and the reaction (Zhou, 2004) while learning is considered to have taken place when a change occurs in the behaviour as a result of the repetition of the stimulant and the resulting reaction (Mechlova and Malcik, 2012; Deubel, 2003; Schunk, 2014). In this approach which explains learning as strengthening the stimulant-reaction connection, there should not be any suspicion on what the stimulant leading to the behaviour is. The main role of the education in the learning process is to create the stimulant-reaction connection (Ertmer and Newby, 2016). Thus, initiation of the process with a single natural and context-free stimulant can be recommended (McKenna and Laycock, 2004).

In a behaviourist instructional environment or material, learning is explained with the stimulant, reaction, and the reward/punishment cycle related to the reaction. Reaction of the student to an ambient stimulant is compulsory for the completion of a behaviourist instructional practice, and the student is obliged to react (Kay and Kibble, 2016; Hassan, 2011). One of the significant stimulants which compel individuals to react and render reaction inevitable is the question. On condition that they lead to the reaction, other stimulants can be used as well, but questions are a significant stimulant in instructional environments and materials. As stated by Bognar (2016), in the behaviourist approach, instructional materials provide a framework of fragmented and elaborated series. This framework consists of statements and questions. If a student answers a question correctly, the process will allow them to proceed to the next part. The behaviourist approach interprets the student's correct answer as the sign of a successful conditioning and continues the behavioural enhancement by rewarding the correct reactions (Boghossian, 2006).

The question to be used in the behaviourist environment or material should have a single correct answer. The answer must be clear so that the response by the learner is correct or incorrect. Deciding on awards and penalties should not the hesitation.Additionally, since students are considered to be nonreflective respondents in the learning process (Boghossian, 2006), open-ended questions which require interpretation should be avoided, and as few choices as possible should be offered when multiple-choice questions are asked. It is not a problem for the student to find the correct answer coincidentally by trial and error for questions having few choices (Aliakbari et al., 2015; Hean, Craddock and O'Halloran, 2009). Learning can take place via a reward gained thanks to a correct answer found by chance (Kay and Kibble, 2016; Aliakbari et al., 2015; Hassan, 2011).

In the behaviourist approach, repetitions and the use of the reward/punishment cycle are needed for enhancing the behaviour after the stimulant-reaction connection is established. Reward or punishment is given after the behaviour is displayed, and reward aims for permanence if the behaviour is correct while punishment aims for a change in the behaviour if it is wrong (Kay and Kibble, 2016; Aliakbari et al, 2015). There is only one correct reaction of the student to the stimulant which results in the reward and all other reactions are considered wrong and requiring punishment (Burton, Moore and Magliaro, 2004). The feedback, which makes the reaction 708 

permanent or ensures learning, is the reward. The student, who is rewarded in response to his reactions, becomes motivated and frequent rewards activate the intrinsic motivation mechanism resulting from the success. As for the punishment, it is applied in the case of a wrong reaction (Kay and Kibble, 2016; Aliakbari et al., 2015). During the learning process, in addition to concrete rewards and punishments to be given as feedback, informative feedbacks stating that the behaviour in question is correct or wrong are also possible (Rizi and Ketabi, 2015; Russell, 2009; Burton, Moore and Magliaro, 2004).

In a behaviourist learning environment or material, the student reacts to the stimulant presented. The student receives feedback on the reaction in the form of reward or punishment. In the learning environment, the student displays a behaviour and receives feedback and learns at his own speed accordingly. Therefore, learning environments or materials based on behaviourist learning theories should be grounded on one-to-one learning and should be arranged in accordance with the self-study principle (Bognar, 2016; Kay and Kibble, 2016; Wu et al., 2012; Burton et al., 2004). In addition, Bloom addressed this principle as a complete success criterion in his complete learning theory (Wong and Kang, 2012; Ghani, Hamim and Ishak, 2006).

Learning tasks or contents are not always easy to learn at one time. In order to overcome this problem, Skinner (1986) proposed the small steps principle. If the behaviour is difficult or complicated, the content can be divided into the smallest subunits and applied in an order (Clemons, 2006; Mergel, 1998; Mishra, 2002). The student is not allowed to proceed to the next task without successfully completing the previous learning tasks (Bognar, 2016; Hassan, 2011). Some researchers have stated that the tasks for the realization of observable behaviours should be arranged in a simple-to-complex and easy-to-difficult order in the behaviourist approach (Deubel, 2003; Aydin, 2000). It can be argued that the small steps principle of Skinner's programmed learning process corresponds to this arrangement from simple to complex or easy to difficult (Akgün and Akgün, 2011; Özbek, 2005; Yaşar, 1989).

In a behaviourist instructional environment or material, education takes places in an integrated manner with assessment (Tamim and Grant, 2016). Since the process focuses on the realization of the desired observable behaviours, the fulfilment of the task by the student means success while the inability of the student to fulfil the task means failure. to be successful, all sequenced tasks should be evaluated separately (Mechlova and Malcik, 2012; Reed, 2012). In a learning environment or material based on behaviourist approach, each one of sequenced tasks serves as the stimulant of the next task and the students are compelled to react to these stimulants. Thus, since learning takes place in the stimulant, reaction and reward/punishment system and the student cannot proceed to the next task without giving the valid reaction to a stimulant in the sequenced tasks, it can be argued that learning can only progress through learning. If an assessment activity is carried out at the end of an unblocked process, it should check only the level of recall. In other words, either the same or very similar questions should be used and the students should be assessed with the same criteria. It should not be forgotten that the aim is to create a clear stimulant-reaction connection. While Khalil and Elkhider (2016) stated that education recall tasks can be used as assessment tools in addition to the multiple-choice questions, Ertmer and Newby (2013) argued that task analysis, behavioural targets, and criteria-based assessment are the types of assessment that can be used in the behaviourist education processes.

\section{Cognitive Learning Theories}

In contrast to the behaviourist approach, which explains learning with the stimulant-reaction connection, cognitive learning theories deal with what happens in the mind of the student. According to cognitive learning theories, such fundamental cognitive processes as attention, perception, memory, problem solving, and metacognition are used in the acquisition and use of knowledge and skills (Schunk, 2014). Learning is identified as the process of receiving, conceptualising, coding, transforming, organizing, repeating, storing, and reusing information (Schunk, 2014; Ertmer and Newby, 2013; Mechlova and Malcik, 2012; Zhou, 2004). Cognitive learning theories consider the student as the active processor of information and deal with how the student processes and stores it during the process (Kay and Kibble, 2016). Knowledge and skills are acquired in the form of schemes or symbolic mental structures and learning is explained as the changes in these structures (Cognitive Approaches to Learning, 2008; Zhou, 2004). These theories try to explain the cognitive activities which increase the significant knowledge levels of the students and contribute to their developments and capacities (Gillani and O’Guinn, 2004; Dobozy and Danziel, 2016).

Cognitive learning theories explain learning on the basis of the basic assumption that the student obtains information by establishing new relations, creating schemes, or organizing the existing schemes. The student learns the new information by building on the existing schemes related to the subject (Mechlova and Malcik, 2012; Mödritscher, 2006; Mergel, 1998). Based on this assumption, it is recommended that the learning process is 
initiated with a number of activities activating the previous knowledge of the student (Tamim and Grant, 2016). In this respect, learning environments and materials should include tools/tests for determining the characteristics of the student (Mergel, 1998). In parallel to this suggestion, Kay and Kibble (2016) applied a pre-test in the cognitive learning environment they prepared in order to determine the previous knowledge of the students. Apart from the determination of the previous knowledge of the students at the beginning of the learning process, some authors suggested instructions or hints that will facilitate learning and explanations motivating for learning (Mergel, 1998). Ertmer and Newby (2013) emphasized the importance of the existence of guiding elements such as instructional explanations, displays, and explanatory examples in the education process.

Determining the characteristics of the learner at the beginning of the education process is important both to determine the previous knowledge of the students and to direct them to the appropriate learning materials during the process. An environment which is diversified or shaped in accordance with the characteristics of the student at the beginning of the process assists in their learning process. Gagne (1965) mentioned the importance of presenting the content in the learning environments at varying forms and levels (cited by $\mathrm{Wu}$ et al., 2012). In instructional materials and environments providing students with personalisation options, the content should be presented from different learning levels in different formats and various practices (Alzaghoul, 2012; Romero et al., 2000).

In cognitive learning theories, some instructional principles assisting the acquisition of knowledge and skills and the development of relations and schemes are the known-to-unknown, easy-to-difficult, and simple-tocomplex principles, etc. (Tamim and Grant, 2016; Edgar, 2012; Krause, Bochner and Duchesne, 2003; Romero et al., 2000; Mergel, 1998). When it is thought that the cognitive learning process relies on the understanding that a student improves the schemes on the basis of the existing schemes, complex information should be presented with the information forming its basis. The activities in the education and learning processes encourage the students to think about and analyse a specific subject in increasingly more complicated ways (Krause, Bochner and Duchesne, 2003). It is seen that this principle is applied in some practices based on cognitive learning theories (Kay and Kibble, 2016; Wu et al., 2012).

In a learning process based on cognitive understanding, transitions in the content presented to the students are not dependent on the reactions of the student as in behaviourist learning approaches. Since a task does not serve as the stimulant of the next task in a cognitive learning environment or material, the student can pass to the next phase without completing the previous one. In the study where they examined the theoretical foundations of gamebased learning, Wu et al. (2011) emphasized this principle by stating that the students had control over the instructional game and could play in the sections they wished.

Informative feedback is one of the significant elements for a cognitive instructional environment or material. According to Romero et al. (2000), in an online instructional design based on cognitive learning theories, students should be provided with warnings in case of misconceptions and informative feedbacks to correct their errors. However, these informative feedbacks are not limited to "correct or wrong" statements as in behaviourism. In cognitive learning environments, feedback assessing the conception as correct or wrong should be supported by different informative feedback in explanatory or thought-provoking form (Ertmer and Newby, 2013).

In a learning process based on cognitive understanding, assessment is not integrated with learning as in behaviourist learning theories and requires an additional assessment and evaluation module. More importantly, the learner should be expected to implement the task in different but related situations rather than a direct implementation in the assessments based on cognitive learning understanding (Gagne, 1970; Wu et al., 2012).

Students might be asked for explanations about the choices they make in the multiple-choice questions directed in the cognitive learning environment or material (Mechlova and Malcik, 2012). Questions with higher numbers of distracters or open-ended questions might be recommended. However, for a valid and comparable process, questions should have specific correct answers. Also, concept maps can be used for assessment in order to see how the students organize and associate the concepts learned in the content (Kay and Kibble, 2016; Khalil and Elkhider, 2016).

\section{Constructivist Learning Theories}

According to constructivist learning theories, learning is the individuals' process of forming subjective knowledge and meanings (Girvan and Savage, 2010). The individuals form and construct their own knowledge in each process (Mechlova and Malcik, 2012; Sen, 2011). In other words, the constructivist perspective is based on the idea that human beings are constructivist. Thus, an instructional material or environment should be arranged 710 

in order to create environments suitable for the constructivist nature of the individuals, not to enable them to construct (Jonassen, 1994).

Constructivist learning theories argue that individuals learn in realist learning environments and social environments by using multiple viewpoints and their own self-awareness (Reed, 2012; Lainema and Makkonen, 2003; Jonassen, 1994). In a constructivist education process where all types of opinions are respected and individuals can select and address the information in line with their needs, aims, beliefs, and other personal experiences, individuals play a key role by taking the responsibility of decisions and control over their own learning processes and also by evaluating their learning processes (Bay, Kaya and Gündoğdu, 2010; Zhou, 2004). It is thought that the statements of teachers or students during the learning process dominate and restrict the process. Constructivist theories are flexible, holistic, and variable. In this process, anyone can share the information. In this respect, it can be stated that there are no rigid tasks and roles in a constructivist learning environment or material (Aqda, Hamidi and Ghorbandordinejad, 2011).

In the design of a constructivist learning environment or material, researchers draw attention to a situationspecific learning within a context (McKenna and Laycock, 2004). It might be recommended to present the information and skills students are expected to gain embedded in a situation, event, or story. McKenna and Laycock (2004) stated that situation-based scenarios are needed for an authentic learning context and these scenarios are essential for the acquisition of the knowledge and construction of the mental models. In cases where the individual does not have personal experiences, story scenarios are needed in order to make up the knowledge deficiency concerning the context (Sen, 2011). In addition, Sen (2011) stated that constructivist learning environments focus on the solution of a problem, question, or project. Thus, providing students with a question or problem designed with the context during the constructivist education process might be a good start for the process (Jonassen, 1994).

Constructivist theories address learning as the act of an individual to make sense of their experiences (Johnson, 2014). The key point of learning is the integration of the content with real life context (Khalil and Elkhider, 2016; Jonassen, Cernusca and Ionas, 2007). McKenna and Laycock (2004) stated that learning should take place in authentic environments and learning gains can be increased only in this way. Likewise, Karagiorgi and Symeou (2005) stated that learning taking place in authentic environments is important for the association of information as well as meaningful learning. In the education process based on constructivist learning theories, content should be presented in different contexts and conditions (Karagiorgi and Symeou, 2005; Jonassen, 1994). In a learning environment or material based on this approach, the content focuses on the transfer of the knowledge and skills in the current learning process to those in the contexts offered (Ertmer and Newby, 2013).

While the student carries out a subjective construction, what individuals share with one another, the use of multiple viewpoints, and the interactions of these viewpoints occupy an important place as well (Aliakbari et al., 2015; Johnson, 2014; Tinker, 1997; Cennamo, Abell and Chung, 1996; Jonassen, 1994). Kanjug and Chaijaroen (2012) stated that learning environments designed with a constructivist approach to enable the students to acquire the desired knowledge and skills and to form mental models without spending time and exerting efforts should support such behaviours as establishing dialogues, knowledge sharing, reflecting individual meanings, and interacting. Some researchers have mentioned that the students need to question different understandings and explain their own perspectives in a constructivist learning environment or material (Aqda, Hamidi and Ghorbandordinejad, 2011; Karagiorgi and Symeou, 2005; McKenna and Laycock, 2004).

The assessment phase of a constructivist learning process is almost completely different from those of behaviourist and cognitive theories. A constructivist assessment does not aim to determine the level of the behaviour or knowledge the student has but is considered an improvement tool which is necessary for supporting learning and improving self-awareness and thus should be used frequently (Hassan, 2011). A constructivist assessment is based on the common opinion of the self, peer, and teacher and considers the entire process rather than the performance of the student in a specific moment. The aim is to determine the processes of thinking rather than the behaviours or knowledge gained by the students (Karagiorgi and Symeou, 2005). Assessment is carried out to obtain development data, not to produce data for comparison (Erdem and Ekici, 2016).

Cunningham and Duffy (1996) stated that the constructivist assessment processes should include concept maps, product files, performance tests, and group tests as tools and verbal statements, group discussions, information transfers, and problem-solving process records as techniques. Semerci (2001) emphasized the use of open-ended exams, performance-based assessment, personal interviews, and personal development files as constructivist exam types. Vural (2005) stated that such methods as discussions, presentations, experiments, exhibitions, projects, 
observations, interviews, and development files should be used. Khalil and Elkhider (2016) argued in their study that peer review and critique can be used as constructivist assessment tools. While questions are given with their validity conditions in the assessment of a constructivist education process, these conditions must be taken into consideration in the answers, which can vary according to the validity conditions (Erdem and Ekici, 2016; Sen, 2011). Thus, an environment based on constructivist learning theories should not have multi-choice questions with a single correct answer. Expecting only one correct answer is contradictory to the argument that the meaning of an individual matters.

As it is seen in the above example, applying an explanatory theory is more difficult than developing it. Although it has been argued that it is more feasible for instructors to try to develop instructional design theories instead of seeking ways for applying the explanatory theories (Pogrow, 1996 cited by Reigeluth 1999: 15), there are many suggestions and principles of the learning theories, which are definite enough, concerning the design of the learning environments. These principles should be taken into consideration while designing education processes. An education environment or process can explain or justify itself in terms of the processes and results only with the learning theory or understanding on which it is based. Based on this understanding, certain criteria which allow for designing an online learning material or environment and examining the existing materials or environments in order to predict the learning understanding on which they are based were developed in the present study.

\section{Method}

A scale functioning as a set of criteria to determine the learning theory on which instructional materials and environments are based and to design learning environments based on a specific learning theory was developed.

\section{Data Collection}

For the purpose of the study, , instructional activity statements, which are thought to represent the reflections of the behaviourist, cognitive, and constructivist learning approaches, were formed and experts were asked their opinions to determine the learning approaches that the statements represent. Based on the expert opinions, statements were revised and the necessary adjustments were made. In the end, a 5-point Likert type scale consisting of 70 items was obtained.

In the following step, different materials were examined by using these items in order to clearly determine the observability of the items in a learning environment or material and complete the deficiencies. To this end, the open access materials available in the Educational Informatics Network (EBA), an online education platform operated by the General Directorate of Innovation and Education Technologies, were used. Six materials of different types available on the platform were examined separately by 3 researchers using the items of the scale. Items were then evaluated again.

Scores ranged from 1 to $5(1=$ Shows the feature specified in the item at a very low level; $5=$ Shows the feature specified in the item at a very high level). Following the assessment, 4 researchers examined items which received highly varied scores and all scores were calculated again. Conformity among the assessments were calculated as $.79, .75, .88, .91, .90$, and .83 for "English 9", "Word group", "Mathematical tools", "Mathematics", "Structure in paragraph", and "SanLab", respectively. Some of the items were excluded from the scale in this step and the final scale consisting of 60 items was tested for content validity. The data collection process is visualized in Figure 1 for a better understanding. 
- To this end, instructional activity statements, which are thought to represent the reflections of the behaviourist, cognitive, and constructivist learning approaches, were formed.

-Experts were asked their opinions to determine the learning approaches that the statements represent.

- Based on the expert opinions, statements were revised and the necessary adjustments were made. (70 items)

- Different six EBA materials were examined by using these items in order to clearly determine the observability of the items in a learning environment or material and complete the deficiencies.

-Six materials were examined separately by 3 researchers using the items of the scale. Items were then evaluated again. (60 items)

-The content validity of the simplified scale of Lawshe technique was calculated.

\section{Figure 1. Data collection process}

\section{Content Validity}

Experts were consulted to examine the content validity of the scale. Experts were asked to assess the items of the scale in terms of compliance with theory, feasibility, and observability, and the content validity of the items were analysed through content validity ratios and indices known as Lawshe technique. This technique consists of six phases (Lawshe, 1975). (Figure 2)

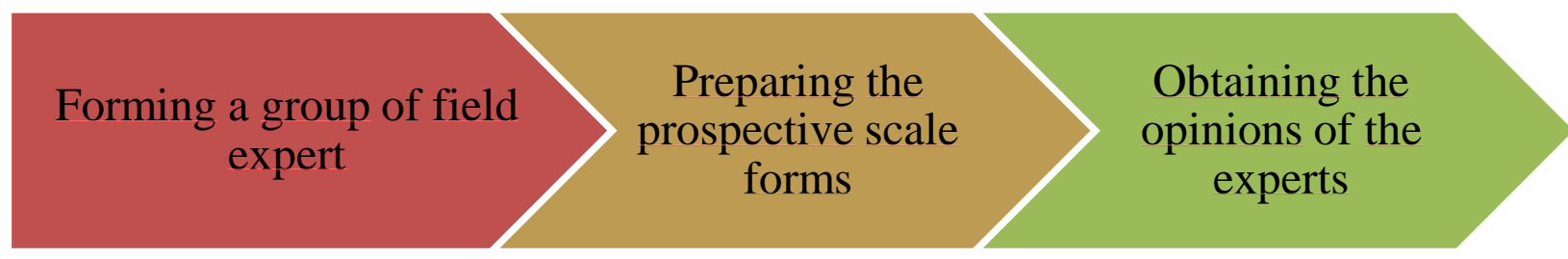

\section{Developing the final form according to the content validity ratios/indices.}

Calculating the content validity indices of the scale
Ccalculating the content validity ratios of the items 
Figure 2. Six phases of Lawshe technique

\section{Scoring of the Scale}

This 5-point Likert type scale was composed of three sub-dimensions consisting of 20 items each. There were 20 items representing the behaviourist, cognitive, and constructivist learning theories. Thus, the minimum score to be obtained from each sub-dimension was 20 while the maximum score was 100 . The theoretical basis of the learning environment and material was determined to be the sub-dimension with the highest score. A calculation of a total score for the whole scale was not made.

\section{Findings}

Twenty-six experts from the field were chosen to test the content validity of the scale. Prospective scale forms were prepared and expert opinions were received online. The items were categorized as "Necessary $(\mathrm{N})-$ the item measures the targeted structure", "Useful/Unnecessary $(\mathrm{U} / \mathrm{U})$ - the item is associated with the structure but is unnecessary", and "Unnecessary (U) - the item does not measure the targeted structure". After this categorization, content validity ratios of the items were obtained. According to Lawshe (1975), the content validity ratio (CVR) is obtained by deducting 1 from the ratio of the number of the experts categorizing the item as "Necessary" to the half of the number of the experts expressing opinions on the item.

\section{$C V R=N G N / 2-1($ Equation 1)}

CVRs of the items were obtained through Equation 1. While the items whose CVRs were found to be 0 and negative were eliminated first, the items with positive CVRs were tested for significance. While significance values of the items with positive CVRs are calculated, content validity criterion (CVC) of the items are determined. While cumulative normal distribution was used to determine the CVC, the criteria having the significance level of .05 were expressed with the values shown in Table 1 for ease of calculation (Veneziano and Hooper, 1997). According to this table, values concerning the number of experts represent the significance values of the items as well.

Table 1. Content Validity Criteria at Significance Level of .05 of the Scale (Veneziano \& Hooper, 1997)

\begin{tabular}{cccc}
\hline Number of experts & Minimum value & Number of experts & Minimum value \\
5 & 0.99 & 13 & 0.54 \\
6 & 0.99 & 14 & 0.51 \\
7 & 0.99 & 15 & 0.49 \\
8 & 0.78 & 20 & 0.42 \\
9 & 0.75 & 25 & 0.37 \\
10 & 0.62 & 30 & 0.33 \\
11 & 0.59 & 35 & 0.31 \\
\hline
\end{tabular}

Taking Table 1 as reference,.36 was accepted as the valid CVC for the items for which 26 experts delivered opinions while .43 was accepted as the valid CVC for Item 57 and Item 58, for which 19 experts delivered opinions. Content validity indices of the scale were determined by comparing the values given in Table 1 as well.

The content validity index (CVI) of the scale was obtained from the total CVR means of the items which had a significance level of .05 and were included in the final scale. In addition, the CVIs of the factors were obtained by taking the CVRs of the items included in the factors. CVRs and CVIs expressing the compliance of the scale with theory as well as its feasibility, and observability are given in Appendix 1. Item 2 (p>.05) did not meet the 
Özer-Şanal\&Akçay\&Çiçek-Tutulmaz\&Erdem validity criteria in terms of feasibility within the scope of the items considered as indicators of the behaviourist learning approach. As for the items representing the cognitive learning understanding, Item 25 had a lower value in terms of compliance with theory. Other items of the scale had adequate content validity values in all aspects (compliance with theory, feasibility, and observability). The content validity indices of the sub-dimensions of the scale were $.78(\mathrm{p}<.05), .87(\mathrm{p}<.05)$, and $.85(\mathrm{p}<.05)$ in behaviourism, cognitive understanding, and constructivism, respectively, in terms of compliance with theory. In terms of the feasibility of the feature expressed in the item, CVIs were $.84(\mathrm{p}<.05), .88(\mathrm{p}<.05)$, and $.85(\mathrm{p}<.05)$ for behaviourism, cognitive understanding, and constructivism, respectively. CVIs for observability, which assesses whether the feature expressed in the item can be observed in the environment or material, were $.89(\mathrm{p}<.05), .92(\mathrm{p}<.05)$, and $.89(\mathrm{p}<.05)$ in behaviourism, cognitive understanding, and constructivism, respectively. The overall CVIs of the scale were $.81(\mathrm{p}<.05), .85$ $(\mathrm{p}<.05)$, and $.88(\mathrm{p}<.05)$ for compliance with theory, feasibility, and observability, respectively. Based on the validity of the calculated CVI values of the scale, problematic items were corrected and retained. The final scale consisted of 60 items with 20 items for each learning theory (Appendix 1).

\section{Discussion and Conclusion}

In the present study, a set of agreed criteria was developed to enable the development and examination of online instructional environments and materials from the perspective of learning theories.

It is thought that the criteria set obtained in this study will be useful in examining existing instructional environments and materials or developing new environments and materials. As a platform where instructional materials and environments produced by teachers in Turkey are shared, the EBA is expected to support the production of materials and environments of high quality and to guide teachers in the development of new materials and environments. Otherwise, especially when the education system is considered, the resulting products may not be acceptable or personal criteria will stand out in the development and assessment of these products. The scale developed within the scope of this study might ensure consistency and increase the quality of the products.

The design of an instructional process, environment, or material should rest on the explanations of learning theories concerning what learning is and how it takes place. As stated above, an instructional environment or material can explain and justify itself in terms of its processes and results only with the learning theory or understanding on which it is based. Seels and Glasgow (1990: 3-4) explained this requirement by stating that, "Instructional design is the process of the systematic development of instructional practices, which pave the way for qualified learning, based on education and learning theories. Education cannot be coincidental, it requires welldesigned processes and it should generate observable outputs". Furthermore, "the duty of the instructional designers and instructors is to put the learning and education principles into practices for instructional materials and activities" (Smith and Ragan, 1993: 12).

Reflecting the learning theories into instructional processes and transforming them into instructional practices are considerably challenging. Thus, the theories' learning explanations and practices should be distinguished (Hung, 2001). How and when are the education targets determined, how is the content formed, how are the instructional activities organized, and how and when is learning tested according to the learning theory taken as the basis? Determining the overall reflection of the answers of these questions on an online learning environment or material might be a second challenge. This study was conducted to support instructional designers by helping them overcome such challenges and ensuring compliance between learning theory and instructional practice. Clarity to be achieved with respect to the reflections of the theories on instructional materials or environments via practices might be useful in developing new materials as well as improving the existing ones. 
Özer-Şanal, S., Akçay, A., Çiçek-Tutulmaz, M. \& Erdem, M. (2019). Application of Learning Theories in Online Instructional Environments and Materials: A Study for Developing a Set of Criteria. Bartın University Journal of Faculty of Education, 8(2), 707-732.

\section{Öğrenme Kuramlarının Çevrimiçi Öğretim Ortamlarında ve Materyallerinde Uygulanması: Bir Ölçütler Takımı Geliştirme Çalışması}

\section{Giriş}

Öğretim tasarımı, nitelikli öğrenmeler gerçekleştirmeyi sağlayacak öğretimsel düzeneklerin, öğrenme ve öğretme kuramlarından yararlanılarak sistematik olarak oluşturulması sürecidir. Öğretim rastlantılara bırakılamaz, iyi düzenlenmiş süreçler gerektirir (Seels ve Glasgow, 1990: 3-4). O halde diyebiliriz ki; istenilir sonuçlar veren öğretim etkinlikleri düzenlemek, öğrenmenin ne olduğu ve nasıl gerçekleştiği ile ilgili açıklamaların ne kadar dikkate aldığıyla yakından ilişkilidir. Bu çerçevede bu çalışma, öğrenme kuramlarının öğretim uygulamalarına nasıl dönüştürülebileceği sorusu doğrultusunda gerçekleştirilmiştir. Çalışmada çevrimiçi öğretim ortam ya da materyalleri içerikleri ve etkileşim dinamikleri esasında ele alınmıştır.

\section{Davranışçı Öğrenme Kuramları}

Davranış̧ı öğrenme kuramlarına göre öğrenme, spesifik çevresel bir uyarıcıya uygun tepkinin verilmesidir (Ertmer ve Newby, 2013). Gözlenebilir davranışın biçiminde ya da sıklı̆ı̆ında bir değişim meydana geldiğinde, öğrenme gerçekleşmiş demektir (Schunk, 2014). Davranış̧̧ı kuramlar öğrencilerin mevcut bilgi yapılarıyla ya da zihinsel süreçleriyle ilgilenmezler. Öğretim hedeflerinde açık ve net bir biçimde belirtilen gözlenebilir davranışları üretmek üzerine odaklanırlar. Bu bakımdan davranışçı yaklaşımlı öğrenmede, öğretimin başarılı bir şekilde tamamlanması ve bu hedeflere ulaşabilmek adına hedef davranışların kazanılması için sürecin bir makine mantığı ile tüm aşamalarının açık bir şekilde tanımlanması ve planlanması gerekir (Mechlova ve Malcik, 2012; Reed, 2012; Tennyson, 2010).

Davranış̧ı bir yaklaşımda öğrenme, uyarıcı ile tepki arasında görülebilir ve güvenilir bir bağlantı olması ile sağlanırken (Zhou, 2004); öğrenme durumu davranışı meydana getiren uyarıcı ve buna bağlantılı olarak verilen tepkinin tekrarlanması ile oluşan davranış değişikliğidir (Mechlova ve Malcik, 2012; Deubel, 2003; Schunk, 2014). Öğrenme durumunu uyarıcı-tepki bağını güçlendirmek olarak açıklayan yaklaşımda davranışı oluşturacak uyarıcının ne olduğuna ilişkin herhangi bir şüphe olmaması gereklidir. Öğretmenin öğrenme sürecindeki başlıca rolü uyarıcı-tepki bağını oluşturmaktır (Ertmer ve Newby, 2016). Bundan dolayı sürecin tek bir doğal ve bağlamdan bağımsız uyarıcı ile başlaması önerilebilir (McKenna ve Laycock, 2004).

Davranış̧̧ bir öğretim ortamında ya da materyalinde öğrenme uyarıcı, tepki ve tepkiye verilecek ödül/ceza döngüsü ile açıklanmaktadır. Öğrencilerin çevreden gelen uyarıcılara tepki vermesi davranışçı bir öğretimsel düzeneğin tamamlanması için zorunludur ve öğrenci tepki vermekle yükümlüdür (Kay ve Kibble, 2016; Hassan, 2011). Döngünün oluşturulabilmesi için bireyin tepkisi şarttır. Bireyi tepkiye zorlayacak, tepkiyi kaçınılmaz kılacak önemli uyarıcılardan biri sorudur. Başka uyarıcılar da, eğer tepkiyi oluşturabiliyorsa kullanılabilir elbette ama soru öğretim ortamları ve materyallerde önemli bir uyarıcıdır. Bognar'ın (2016) da belirttiği gibi davranışçı yaklaşımda, öğretim materyali parçalara bölünmüş, dikkatle geliştirilmiş diziler çerçevesi sunar. Bu çerçeve ifadelerden ve sorulardan oluşur. Bir öğrenci verilen soruyu doğru bir şekilde cevaplayacak olursa, süreç bir sonraki parçaya geçmesine izin verecektir. Davranış̧̧ı yaklaşım, bir öğrencinin soruya verdiği doğru cevabı, başarılı bir koşullanmanın işareti olarak yorumlayacak ve sonrasında doğru tepkileri ödüllendirerek davranışsal olarak pekiştirmeye devam edecektir (Boghossian, 2006).

Davranışçı ortam ya da materyallerde kullanılacak sorunun öncelikle tek doğru cevaplı olması gerekir. Öğrenen tarafından tepkinin doğru ya da yanlış olduğunun kesinlikle söylenebilmesi için cevap net olmalıdır. Ödül ve cezaya karar verme sorunun yaşanmamalıdır. Bu duruma ek olarak, öğrenme sürecinde öğrenci yansıtmayan bir yanıtlayıcı olarak görüldüğünden dolayı (Boghossian, 2006) açık uçlu, yorum gerektiren sorulardan kaçınmak, çoktan seçmeli soru sorulması durumunda da mümkün olduğunca az seçenek sunmak önemlidir. Az seçenekli sorularda doğru cevabın, deneme-yanılma yolu ile tesadüfen bulunması sorun değildir (Aliakbari ve diğerleri, 2015; Hean, Craddock ve O'Halloran, 2009). Tesadüfen bulunan bir doğru cevap sayesinde kazanılan ödül yoluyla öğrenme gerçekleştirilebilir (Kay ve Kibble, 2016; Aliakbari ve diğerleri, 2015; Hassan, 2011).

Davranış̧ı bir yaklaşımda, uyarıcı-tepki bağının kurulmasının ardından davranışın gü̧̧lenmesi için yapılacak olan, çok tekrar ve ödül/ceza uygulamasıdır. Ödül veya ceza davranış gösterildikten sonra verilmekte ve davranış doğru ise ödülle kalıcılığı, yanlış ise ceza ile değiştirilmesi sağlanmaktadır (Kay ve Kibble, 2016; Aliakbari ve diğerleri, 2015). Öğrencinin uyarıcıya verebileceği ve ödül alacağ tek doğru tepki vardır ve bu tepkinin dışındaki her tepkisi yanlış olarak değerlendirilir ve ceza alır (Burton, Moore ve Magliaro, 2004). Çünkü tepkiyi kalıcı kılan yani öğrenmeyi sağlayan dönüt ödüldür. Tepkilerine ödül alan öğrenci, devamı için güdülenir ve sık ödüllenme 
öğrencinin başarıdan gelen içsel güdülenme mekanizmasının çalışmasını sağlar. Ceza ise değişmesi gereken, yanlış olan tepkiye verilir (Kay ve Kibble, 2016; Aliakbari ve diğerleri, 2015). Öğrenme sürecinde, dönüt olarak verilebilecek somut ödüllerin ve cezaların yanında, gerçekleştirilen davranışın sadece doğru ya da yanlış olduğuna yönelik bilgilendirici dönütte verilebilir (Rizi ve Ketabi, 2015; Russell, 2009; Burton, Moore ve Magliaro, 2004).

Davranışçı bir öğrenme ortamında ya da materyalinde öğrenci kendisine sunulan uyarıcıya tepki gösterir.Öğrencinin tepkisine de ödül veya ceza yolu ile dönüt verilir. Öğrenci öğrenme ortamında kendisi davranış göstermekte, buna yönelik dönüt almakta ve kendi hızında öğrenmektedir. Dolayısıyla davranışçı öğrenme kuramlarına dayalı öğrenme ortam ya da materyalleri birebir öğrenmeyi esas almalı, bireysel çalışma ilkesine göre düzenlenmelidir (Bognar, 2016; Kay ve Kibble, 2016; Wu ve diğerleri, 2012; Burton ve arkadaşları, 2004). Ayrıca Bloom'da tam öğrenme kuramında bu ilkeyi, tam başarı ölçütü olarak ele almıştır (Wong ve Kang, 2012; Ghani, Hamim ve Ishak, 2006).

Öğrenme görevleri ya da içerikler her zaman bir seferde öğrenilecek kadar kolay olmamaktadır. Bunu aşmak için Skinner (1986), küçük adımlar ilkesini önermektedir. Davranışın zor veya karmaşık olması durumunda içerik, en küçük alt birimlere bölünerek verilmekte ve sıralanmış bir şekilde uygulanmaktadır (Clemons, 2006; Mergel, 1998; Mishra, 2002). Sıralanan öğrenme görevlerden biri başarı ile tamamlanmadan diğerine geçmeye de izin verilmemektedir (Bognar, 2016; Hassan, 2011). Bazı araştırmacılar davranışçı yaklaşımda gözlemlenen davranışları gerçekleştirme görevlerinin basitten karmaşığa ve kolaydan zora doğru sıralanması gerektiğini belirtmişlerdir (Deubel, 2003; Aydın, 2000). Skinner'ın programlı öğretim sürecinin küçük adımlar ilkesinin, basitten karmaşığa ya da kolaydan zora düzenleme ilkesini karşıladığı söylenebilir (Akgün ve Akgün, 2011; Özbek, 2005; Yaşar, 1989).

Davranışçı bir öğretim ortamında veya materyalinde öğretim, değerlendirmeyle entegre bir biçimde gerçekleşir (Tamim ve Grant, 2016). Süreç, istendik gözlemlenebilen davranışların gerçekleştirmesi üzerine odaklandığından; öğrencinin görevi yapması başarı, yapmaması ise başarısızlık olarak değerlendirilmektedir. Öğretimin başarılı olarak nitelendirilebilmesi için sıralı görevlerin tek tek değerlendirilmesi gerekmektedir (Mechlova ve Malcik, 2012; Reed, 2012). Davranışçı bir yaklaşıma dayalı öğrenme ortamında ya da materyalinde sıralı görevlerin her biri bir sonrakinin uyarıcısı olmakta ve öğrenciler bu uyarıcılara tepki vermek zorunda bırakılmaktadırlar. Bu yüzden, öğrenme; uyarıcı, tepki, ödül/ceza dizgesinde gerçekleşir. Öğrenci sıralı görevlerde bir uyarıcıya geçerli tepkiyi vermeden diğerine geçemeyeceği için öğrenmenin ancak öğrenerek ilerleyebileceği söylenebilir. Dolayısıyla süreç sonunda bir değerlendirme etkinliği düzenlenirse ki; buna bir engel yoktur, bu sadece hatırlamayı yoklamalıdır. Yani öğretimde kullanılan soruların aynısı ya da çok benzeri kullanılmalı ve öğrenciler aynı ölçütlerle değerlendirilmelidir. Net bir uyarıcı tepki bağı oluşturulmaya çalışıldığı unutulmamalıdır. Khalil ve Elkhider (2016), çoktan seçmeli soruların yanında, öğretimi hatırlama görevlerinin de değerlendirme aracı olarak kullanılabileceğini; Ertmer ve Newby (2013) ise görev analizi, davranışsal hedefler ve ölçüt dayanaklı değerlendirmenin davranışçı öğretim süreçlerinde kullanılabilecek değerlendirme türleri olduğunu belirtmişlerdir.

\section{Bilișsel Öğrenme Kuramları}

Bilişsel öğrenme kuramları, öğrenmeyi uyarıcı tepki bağı ile açıklayan davranışçı yaklaşımın aksine, öğrencinin zihninde neler olup bittiği ile ilgilenmektedir. Bilişsel öğrenme kuramlarına göre bilgi ve becerinin elde edilmesi ve kullanılmasında dikkat, algı, hafıza, problem çözme, üst biliş gibi temel biliş süreçleri işler (Schunk, 2014). Öğrenme; bilginin alınması, kavramsallaştırılması, kodlanması, dönüştürülmesi, organize edilmesi, tekrarlanması, depolanması ve yeniden kullanılması süreci olarak tanımlamaktadır (Schunk, 2014; Ertmer ve Newby, 2013; Mechlova ve Malcik, 2012; Zhou, 2004). Bilişsel öğrenme kuramları öğrenciyi bilginin aktif işleyeni olarak görmekte, süreç içerisinde bilgiyi nasıl işlediği ve depoladığıyla ilgilenmektedirler (Kay ve Kibble, 2016). Bilgi ve beceriler şema ya da sembolik zihinsel yapılar olarak kazanılmakta, öğrenme ise bu yapılardaki değişimler olarak açıklanmaktadır (Cognitive Approaches to Learning, 2008; Zhou, 2004). Bu kuramlar, ögrencilerin anlamlı bilgi düzeylerini artıran, gelişimlerine ve kapasitelerine katkıda bulunan bilişsel aktiviteleri açıklamaya çalışmaktadır (Gillani ve O’Guinn, 2004; Dobozy ve Danziel, 2016).

Bilişsel öğrenme kuramları öğrenmeyi, öğrencinin edineceği bilgiyi yeni ilişkiler kurarak, şemalar oluşturarak ya da var olan şemalarını düzenleyerek elde ettiği temel varsayımınına dayalı olarak açıklar. Öğrenci yeni bilgiyi, konu ile ilişkili var olan şemaları üzerine inşa ederek öğrenir (Mechlova ve Malcik, 2012; Mödritscher, 2006; Mergel, 1998). Bu varsayıma dayanarak öğrenme sürecinin, öğrencilerin geçmiş bilgilerini aktif hale getiren bir takım etkinlikler ile başlatılması önerilmektedir (Tamim ve Grant, 2016). Bu bakımdan öğrenme ortamlarında ve materyallerinde öğrenci özelliklerini belirlemeye yönelik araçlar/testler bulunmalıdır (Mergel, 1998). Bu öneriyi 
destekler nitelikte, Kay ve Kibble (2016) hazırlamış oldukları bilişsel öğrenme ortamında öğrencilerin ön bilgilerini belirlemek adına ön-test uygulamışlardır. Öğrenme sürecinin başlangıcında öğrencilerin ön bilgilerinin belirlenmesinin dışında bazı yazarlar tarafından öğrenmeyi kolaylaştıracak yönergeler ya da ipuçları ile öğrenmeye güdüleyici açıklamalar bulunması da önerilmektedirler (Mergel, 1998). Ertmer ve Newby (2013)'da öğretim sürecinde öğretimsel açıklamalar, gösterimler, açıklayıcı örnekler gibi rehberlik edici unsurların olmasının önemini vurgulamaktadır.

Öğretim sürecinin başında öğrenen özelliklerinin belirlenmesi öğrencilerin geçmiş bilgilerini belirlemenin yanında öğrenciyi süreç içerisinde uygun öğrenme materyallerine yönlendirmek adına da önemlidir. Öğrencinin süreç başında belirlenen özelliklerine göre çeşitlendirilen ya da şekillendirilen ortam, öğrencinin öğrenme sürecine yardımcı olmaktadır. Gagne (1965), bu konuya ilişkin olarak öğrenme ortamlarında içeriğin çeşitli formlarda ve seviyelerde sunulmasının öneminden bahsetmiştir (Akt. Wu ve diğerleri, 2012). Öğrencilere kişiselleştirme seçeneklerinin sunulduğu öğretim materyallerinde ve ortamlarında içerik, farklı öğrenme düzeyindeki öğrenciler için farklı formatlarda ve çeşitli uygulamalarda sunulmalıdır (Alzaghoul, 2012; Romero ve diğerleri, 2000).

Bilişsel öğrenme kuramlarında bilgi ve becerilerin elde edilmesi, ilişkilerin ve şemaların oluşturulması için yardımcı bazı öğretimsel ilkeler; bilinenden bilinmeyene, kolaydan zora, basitten karmaşığa vb. ilkelerdir (Tamim ve Grant, 2016; Edgar, 2012; Krause, Bochner ve Duchesne, 2003; Romero ve diğerleri, 2000; Mergel, 1998). Bilişsel bir öğrenme sürecinin, öğrencinin hâlihazırda varolan şemalarından yola çıkarak şemalarını geliştirdiği anlayışına dayandığı düşünülürse; karmaşık bilgilerin, temelini oluşturan bilgilerle ilişkili olarak sunulması beklenir. Öğretim ve öğrenme sürecindeki etkinlikler, öğrencileri belli bir konuyu giderek daha karmaşık yollarla düşünmeye ve analiz etmeye teşvik eder (Krause, Bochner, ve Duchesne, 2003). Bilişsel öğrenme kuramlarını temel alan bazı uygulamalarda bu ilkenin uygulandığı görülmektedir (Kay ve Kibble, 2016; Wu ve diğerleri, 2012).

Bilişsel anlayışa dayalı bir öğrenme süreci içerisinde öğrencilere sunulan içerik geçişleri, davranışçı öğrenme yaklaşımlarında olduğu gibi öğrenci tepkilerine bağımlı değildir. Bilişsel bir öğrenme ortamı ya da materyalinde bir görev bir sonraki görevin uyarıcısı olmadığından öğrenci bir aşamayı tamamlamadan diğerine geçebilmektedir. Oyun tabanlı öğrenmenin kuramsal temellerini inceledikleri çalışmalarında Wu ve diğerleri (2011), bu ilkeyi, öğrencilerin eğitsel oyun üzerinde kontrol sahibi olduklarını ve kendi istedikleri bölümlerde oynayabileceklerini belirterek vurgulamışlardır. Bilgilendirici dönüt, bilişsel bir öğretim ortamı ya da materyali için önemli unsurlardan biridir. Romero ve arkadaşları (2000)'na göre bilişsel öğrenme kuramlarına dayanan çevrimiçi bir öğretim tasarımında öğrencilere, yanlış kavrama durumlarında uyarılar ve hatalarını düzeltmelerine yardımcı olacak bilgilendirici dönütler verilmelidir. Ancak sözü edilen bilgilendirici dönüt davranış̧̧1lıtaki gibi "doğru ya da yanlış" önermeleriyle sınırlı değildir. Bilişsel öğrenme yaklaşımına dayalı ortamlarda doğru ya da yanlış bilgisi veren dönütler açıklayıcı ya da düşündürücü formda farklı bilgilendirici dönütlerle desteklenmelidir (Ertmer ve Newby, 2013).

Bilişsel öğrenme ortam veya materyalinde değerlendirme, davranışçı öğrenme kuramlarındaki gibi öğrenmeyle bütünleşik değildir. Ayrıca bir ölçme değerlendirme modülü gerektirir. Ayrıca ve daha önemli olarak bilişsel öğrenme anlayışına dayalı değerlendirmelerde görevin, birebir yerine getirilmesi değil, ilişkili farklı durumlarda uygulaması beklenmelidir (Gagne, 1970; Wu ve diğerleri, 2012). Bilişsel öğrenme ortamı ya da materyalinde yöneltilen çoktan seçmeli sorularda öğrencinin yaptığı seçimlere açıklama getirmesi istenebilir (Mechlova ve Malcik, 2012). Çeldirici sayısı fazla ya da açık uçlu sorular kullanılması önerilebilir. Ancak geçerli ve karşılaştırmaya izin verecek bir süreç için, soruların belli bir doğru cevabı olmalıdır. Bunun dışında öğrencinin içerikte öğrendiği kavramları nasıl organize ettiğini ve nasıl ilişkilendirdiğini görmek adına kavram haritaları kullanarak da değerlendirme yapılabilir (Kay ve Kibble, 2016; Khalil ve Elkhider, 2016).

\section{Yapılandırmacı Öğrenme Kuramları}

Yapılandırmacı öğrenme yaklaşımlarına göre öğrenme, bireylerin öznel bilgi ve anlam oluşturma sürecidir (Girvan ve Savage, 2010). Birey her süreçte kendi bilgisini oluşturur, yapılandırır (Mechlova ve Malcik, 2012; Sen, 2011). Başka bir ifadeyle yapılandırmacı görüş, insanın yapılandırmacı olduğu fikri üzerine temellenir. Dolayısıyla yapılandırmacı bakış açısına göre bir öğretim materyali ya da ortamı, bireyin yapılandırmasını sağlamak için değil; onun yapılandırmacı doğasına uygun ortamlar oluşturmak üzere düzenlenmelidir (Jonassen, 1994).

Yapılandırmacı öğrenme kuramları, bireyin öğrenmeyi gerçekçi öğrenme ortamlarında, sosyal ortamlarda çoklu bakış açılarını değerlendirerek, kendi öz farkındalığını kullanarak gerçekleştirdiğini savunmaktadır (Reed, 
2012; Lainema ve Makkonen, 2003; Jonassen, 1994). Yapılandırmacı bir öğretim sürecinde bireyler, kendi öğrenmelerine ilişkin karar ve kontrolün sorumluluğunu aldıkları, her türlü düşüncelerinin saygıyla karşılandığı; ihtiyaçları, amaçları, inançları ve diğer kişisel deneyimleri ile bilgileri seçip ele alabildikleri ve kendi öğrenmelerini değerlendirdikleri bir role sahiptirler (Bay, Kaya ve Gündoğdu, 2010; Zhou, 2004). Öğrenme sürecinde öğretmen ya da öğrenci ifadesinin öğrenme sürecine yön verdiği ve sınırlandırdığı düşünülmektedir. Yapılandırmacı kuramlar esnek, bütüncül, değişken bir yapıdadır. Bu süreçte bilgiyi herkes paylaşabilir. Bu bakımdan yapılandırmacı bir öğrenme ortamında veya materyalinde kalıplaşmış görev ve roller bulunmadı̆̆ söylenebilir (Aqda, Hamidi ve Ghorbandordinejad, 2011).

Yapılandırmacı bir öğrenme ortamı ya da materyalinin tasarlanmasında araştırmacılar, bir bağlam içerisinde duruma özgü öğrenmeye dikkat çekmektedirler (McKenna ve Laycock, 2004). Buna dayanarak süreçte öğrencilere kazandırılmak istenen bilgi ve becerilerin bir durum, olay veya öyküye gömülü biçimde sunulması önerilebilir. McKenna ve Laycock (2004) otantik bir öğrenme bağlamı için durum tabanlı senaryolar oluşturulması gerektiğini ve bu senaryoların bilginin kazanılması ve zihinsel modellerin yapılanması için önemli olduğunu belirtmiştir. Bireyin kişisel deneyim yaşamadığı durumlarda bağlama yönelik bilgi eksikliğini tamamlaması için öykü senaryoları gereklidir (Sen, 2011). Ayrıca Sen (2011) yapılandırmacı öğrenme ortamlarının bir problemin, sorunun ya da projenin çözümüne odaklandığını belirtmiştir. Bu bakımdan yapılandırmacı öğretim sürecinde öğrencilere, bağlamı ile birlikte tasarlanmış bir soru ya da problem yöneltilmesi uygun bir süreç başlangıcı olabilir (Jonassen, 1994).

Yapılandırmacı kuramlar öğrenmeyi, bireyin deneyimlerden anlam oluşturması olarak ele almaktadır (Johnson, 2014). Öğrenmenin anahtar noktası içeriğin gerçek yaşam bağlamı ile bütünleşmiş olmasıdır (Khalil ve Elkhider, 2016; Jonassen, Cernusca ve Ionas, 2007). McKenna ve Laycock (2004), öğrencilerin öğrenmelerinin otantik ortamlarda gerçekleştirilmesi gerekliliğini ve öğrenmelerini bu yolla artırabileceklerini ifade etmişlerdir. Karagiorgi ve Symeou (2005) bu durumu destekler nitelikte otantik ortamlarda yapılan öğrenmelerin bilgiyi ilişkilendirebilmesinde ve anlamlı öğrenme sağlamasında önemli olduğunu belirtmiştir. Yapılandırmacı öğrenme kuramlarına dayalı öğretim sürecinde içerik, farklı bağlamlar ya da farklı koşullar çerçevesinde sunulmalıdır (Karagiorgi ve Symeou, 2005; Jonassen, 1994). Bu yaklaşıma dayalı bir öğrenme ortamında ya da materyalinde içerik, mevcut öğrenme sürecindeki bilgi ve becerinin sunulan bağlamlardaki transferine odaklanır (Ertmer ve Newby, 2013).

Yapılandırmacı öğrenme ortamında bireylerin birbirleriyle paylaşımları, çoklu bakış açısından faydalanmaları ve bu bakış açılarının etkileşimleri de önemli bir yere sahiptir (Aliakbari ve diğerleri, 2015; Johnson, 2014; Tinker, 1997; Cennamo, Abell ve Chung, 1996; Jonassen, 1994). Kanjug ve Chaijaroen (2012) öğrencilerin edinmesi istenilen bilgi ve becerileri zaman ve çaba sarf etmesine gerek kalmaksızın elde etmesi ve zihinsel modellerinin oluşması için yapılandırmacı bir yaklaşımla hazırlanan öğrenme ortamlarının öğrencinin diyalog kurma, bilgi paylaşımı yapma, bireyin anlamlarını yansıtma ve etkileşim içerisinde bulunma gibi davranışlarını desteklemesi gerektiğini belirtmiştir. Bazı araştırmacılar yapılandırmacı bir öğrenme ortamı ya da materyalinde öğrencilerin birbirlerinin anlayışlarını sorgulamaları ve kendi bakış açılarını açıklamaları gerektiğine değinmişlerdir (Aqda, Hamidi ve Ghorbandordinejad, 2011; Karagiorgi ve Symeou, 2005; McKenna ve Laycock, 2004).

Yapılandırmacı bir öğrenme sürecinin değerlendirme aşaması ise davranışçı ve bilişsel kuramdan neredeyse tamamen farklılaşmaktadır. Yapılandırmacı bir değerlendirme, öğrencide var olan davranışın veya bilginin düzeyini belirlemek için değil, öğrencilerin öğrenmelerini desteklemek, öz-farkındalığını geliştirmek için gerekli olan; sık sık gerçekleştirilmesi gereken bir geliştirme aracı olarak görülür (Hassan, 2011). Yapılandırmacı bir değerlendirme öz, akran ve öğretmenin ortak görüşüne dayalıdır ve öğrencinin belirli bir andaki performansı değil, tüm süreci dikkate alınır. Amaç öğrencilerin edindiği davranışları veya bilgileri belirlemek değil, düşünme süreçlerini belirlemektir (Karagiorgi ve Symeou, 2005). Değerlendirme, karşılaştırma verisi üretmek için değil gelişim verisi elde etmek için yapılır (Erdem ve Ekici 2016).

Cunningham ve Duffy (1996) yapılandırmacı değerlendirme süreçlerinde; araç olarak kavram haritalarına, ürün dosyalarına, performans testlerine, grup testlerine yer verilmesi gerektiğini ve sözel ifade, grup tartışması, bilginin aktarılması, problem çözme süreci kayıtlarının kullanılabilecek teknikler olduğunu ifade etmiştir. Semerci (2001) yapılandırmacı sınav türleri olarak açık uçlu sınav, performansa dayalı değerlendirme, kişisel görüşme ve kişisel gelişme dosyası kullanılmasını vurgulamıştır. Vural (2005) tartışma, sunum, deney, sergi, proje, gözlem, görüşme, gelişim dosyası gibi yöntemlerden yararlanılması gerektiğini belirtmiştir. Khalil ve Elkhider (2016) ise yapmış oldukları çalışmaya dayalı olarak, akran değerlendirmesi ve eleştirisinin yapılandırmacı bir değerlendirme aracı olarak kullanılabileceğini belirtmişlerdir. Yapılandırmacı öğretim süreçlerinde yapılacak değerlendirmede 
sorular geçerlik koşulları ile birlikte verilirken, cevaplama aşamasında bu koşulların dikkate alınması beklenmektedir ve cevaplar geçerlik koşullarına göre değişkenlik içermektedir (Erdem ve Ekici, 2016; Sen, 2011). Dolayısıyla yapılandırmacı öğrenme kuramlarına dayalı bir ortamda çoktan seçmeli, tek doğru cevaplı soru sorulmamalıdır. Bireyin kendi anlamının önemli olduğunu savunuyorsak, tek doğrunun beklenmesi bu görüşle çelişecektir.

Görüldüğü gibi; bir açıklayıcı teoriyi uygulamak onun oluşturulmasından çok daha güçtür ve eğitimcilerin, açıklayıcı teorileri uygulamanın yollarını aramak yerine öğretim tasarım teorileri geliştirmek için çalışmaları çok daha uygun olur (Pogrow, 1996 Akt. Reigeluth 1999: 15) yönünde bazı görüşler ileri sürülmüşse de, öğrenme kuramlarının öğrenme ortamlarının nasıl düzenlenmesi gerektiğine dair çok da belirsiz olmayan birçok önerisi, ilkesi bulunmaktadır. Öğretim süreçleri düzenlenirken bu ilkelerin dikkate alınması önemlidir. Zira bir öğretim ortam ya da süreci, öğreneni maruz bıraktığı süreçler ve sonuçları açısında kendisini ancak dayandığı öğrenme kuram ya da anlayışıyla açıklayabilir, meşrulaştırabilir. Bu anlayışla bu çalışmada, bir çevrimiçi öğrenme materyal ya da ortamını düzenlemeyi, mevcut materyal ya da ortamları, dayandığı öğrenme anlayışını yordamak üzere incelemeyi olanaklı kılacak bazı ölçütler geliştirilmiştir.

\section{Yöntem}

Bu çalışma kapsamında, öğretim materyallerinin ve ortamlarının hangi öğrenme kuramına yakın düştüklerini belirlemek ya da belli bir öğrenme kuramına dayalı öğrenme ortamı tasarlamak için ölçütler takımı işlevi görecek bir ölçek geliştirilmiştir.

\section{Verilerin Toplanması}

Çalışmanın amacı doğrultusunda öncelikle; davranışçı, bilişsel ve yapılandırmacı öğrenme yaklaşımlarının öğretime yansıma biçimlerini temsil ettiği düşünülen öğretim etkinliği ifadeleri oluşturulmuştur. Oluşturulan ifadelerin hangi öğrenme anlayışını temsil ettiği konusunda uzman görüşüne başvurulmuştur. Uzman görüşleri doğrultusunda ifadeler üzerinde yeniden çalışılmış, gerekli düzenlemeler yapılmıştır. Böylece 5 'li likert tipinde 70 maddeden oluşan bir ölçek elde edilmiştir.

Bir sonraki aşamada; ölçekte yer alan maddelerin bir öğrenme ortam ya da materyalinde net olarak gözlenebilirliğini belirlemek ve eksik noktaları tamamlamak için, bu maddeler kullanılarak farklı materyaller incelenmiştir. Bu amaçla Yenilik ve Eğitim Teknolojileri Genel Müdürlüğü tarafından yürütülen çevrim içi bir eğitim platformu olan Eğitim Bilişim Ağında (EBA) yer alan, erişime açık materyallerden yararlanılmıştır. Ortamda bulunan farklı türde 6 materyalin, 3 araştırmacı tarafından ve ölçek maddeleri kullanılarak ayrı ayrı gerçekleştirdikleri incelemeyle, ölçek maddeleri tekrar değerlendirilmiştir.

1-5 (1=Maddede belirtilen özelliği çok düşük düzeyde gösteriyor, 5= Maddede belirtilen özelliği çok güçlü biçimde gösteriyor) arasında puanlanarak gerçekleştirilen değerlendirmenin ardından, 4 araştırmacı özellikle çok farklı puanlanmış maddeleri tekrar incelemiş ve tüm puanlamalar yeniden yapılmıştır. Değerlendirmeler arası uyum düzeyleri incelendiğinde, "İngilizce 9" uygulaması için .79, "Kelime grubu" uygulaması için .75, "Matematik araçları" uygulaması için .88, "Matmatik" uygulaması için .91, "Paragrafta yapı" uygulaması için .90, "SanLab" uygulaması için .83 olarak hesaplanmıştır. Bu süreçte bazı maddeler de ölçekten çıkarılmış, 60 maddelik yeni ölçek kapsam geçerlilik oranlarını belirlemek üzere elde edilmiştir. Verilerin toplanması süreci daha anlaşılır olması için Şekil 1'de görselleştirilmiştir. 


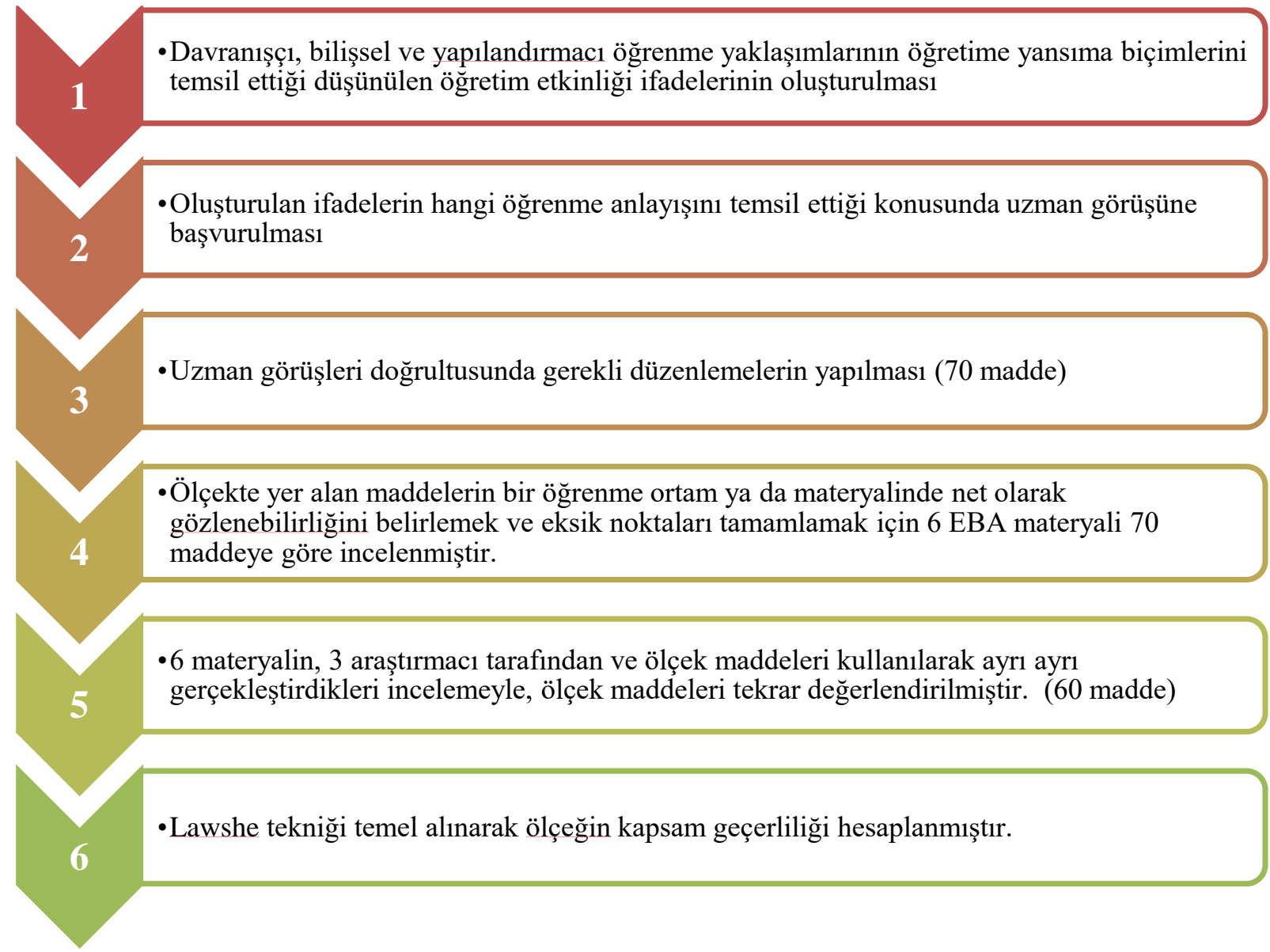

Şekil 1. Veri toplanması süreci

\section{Kapsam Geçerliliği}

Ölçeğin kapsam geçerliğini incelemek amacı ile uzman görüşlerine başvurulmuştur. Uzmanlardan kurama uygunluk, uygulanabilirlik ve gözlemlenebilirlik durumları bakımından incelemeleri istenen maddelerin kapsam geçerliği, Lawshe tekniği olarak bilinen kapsam geçerlik oranları ve indeksleri ile analiz edilmiştir. Bu yaklaşım 6 aşamadan oluşmaktadır (Lawshe, 1975). (Şekil 2)
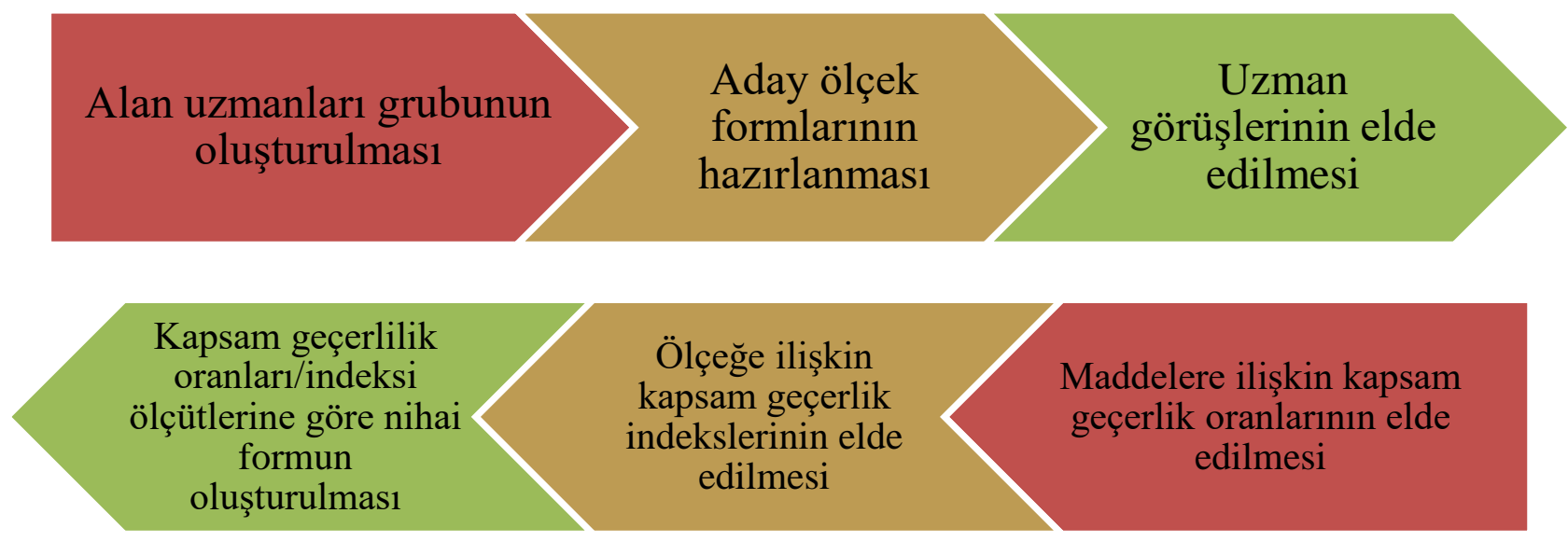
Şekil 2. Lawshe tekniğinin altı aşaması

\section{Ölçeğin Puanlanması}

Ölçek 5'li likert biçiminde hazırlanmıştır ve her biri 20 maddeden oluşan üç alt boyuttan oluşmaktadır. Davranışçı, bilişsel ve yapılandırmacı öğrenme kuramlarını yansıtan 20'şer madde. Dolayısıyla her alt boyuttan alınabilecek minimum puan 20 ve maksimum puan 100'dür. Öğrenme ortam ya da materyalinin kuramsal temeli, daha yüksek puan aldığı alt boyuta göre belirlenmektedir. Ölçeğin bütünü için bir toplam puan hesaplama durumu söz konusu değildir.

\section{Bulgular}

Ölçeğin kapsam geçerliğinin sağlanmasında bu çerçeve temel alınarak 26 kişilik ilgili alanın uzmanları belirlenmiştir. Daha sonrasında aday ölçek formları hazırlanmış ve çevrim içi olarak uzmanlardan görüşler elde edilmiştir. Maddeler uzmanlar tarafından "madde hedeflenen yapıyı ölçüyor" yani "Gerekli (G'li)", "madde yapı ile ilişkili ancak gereksiz" yani "Yararlı/Gereksiz (Y'll/G'siz)" ve "madde hedeflenen yapıyı ölçmez" yani "Gereksiz (G'siz)" olarak kategorize edilmiştir. Bu kategorize işleminden sonra maddelerin kapsam geçerlik oranları elde edilmiştir. Lawshe (1975)'ye göre kapsam geçerlik oranları (KGO), herhangi bir maddeye ilişkin “Gerekli” görüşünü belirten uzman sayılarının maddeye ilişkin görüş belirten toplam uzman sayısının yarısına oranının 1 eksiği ile elde edilir.

\section{$K G O=N G N / 2-1($ Eşitlik 1)}

Maddelerin KGO'ları Eşitlik 1 ile verilen ifade yardımı ile elde edilmiştir.. KGO değerleri 0 ve negatif değer olan maddeler ilk elenen maddeler olurken, pozitif olan maddeler için anlamlılıkları test edilmiştir. KGO pozitif olan maddelerin anlamlılıkları değerlendirilirken, maddelerin kapsam geçerlik ölçütleri (KGÖ) belirlenir. KGÖ belirlemek için birikimli normal dağılımından yararlanılırken, hesaplama kolaylığı açısından .05 anlamlılık düzeyinde KGÖ’ler Tablo 1'de gösterilen değerlerle ifade edilmiştir (Veneziano ve Hooper, 1997). Bu tabloya göre uzman sayısına ilişkin değerler, aynı zamanda maddelerin anlamlılık değerlerini ifade etmektedir.

Tablo 1. Ölçeğin .05 Anlamlılık Düzeyinde Kapsam Ggeçerlik Ölçütleri (Veneziano ve Hooper, 1997)

\begin{tabular}{cccc}
\hline Uzman Sayısı & Minimum Değer & Uzman Sayısı & Minimum Değer \\
\hline 5 & 0.99 & 13 & 0.54 \\
6 & 0.99 & 14 & 0.49 \\
7 & 0.99 & 15 & 0.42 \\
8 & 0.78 & 20 & 0.37 \\
9 & 0.75 & 25 & 0.33 \\
10 & 0.62 & 30 & 0.31 \\
12 & 0.59 & 35 & 0.29 \\
\hline
\end{tabular}

Tablo 1 referans alınarak bu çalışmada, 26 uzmanın görüş belirttiği maddeler için .36 ve 19 uzmanın görüş belirttiği Madde 57 ve Madde58 için .43 geçerli KGÖ olarak alınmıştır. Ölçeğin kapsam geçerlik indeksleri ise yine Tablo 1'de belirtilen değerler ile karşılaştırılarak belirlenmiştir. 
Ölçeğin kapsam geçerlik indeksi (KGI) .05 anlamlılık düzeyinde anlamlı olan ve ölçekte nihai olarak yer alacak olan maddelerin toplam KGO ortalamaları üzerinden elde edilmiştir. Yine faktörlerin KGİ'leri, faktörlerde bulunan maddelerin KGO dikkate alınarak elde edilmiştir. Ölçeğin kurama uygunluğunu, anlaşılırlığını, uygulanabilirliğini ve gözlenebilirliğini belirten KGO'ları ve KGİ'leri Tablo 2'de belirtilmiştir.

Ek 2 incelendiğinde; davranışçı öğrenme anlayışının göstergesi olan maddeler kapsamında yer alan Madde2'nin uygulanabilirlik açılarından geçerliliğinin sağlanamadığı ( $\mathrm{p}>.05)$ görülmüştür. Bilişsel öğrenme anlayışının göstergesi olan maddeler kapsamında yer alan Madde25, kurama uygunluk açısından düşük değer almıştır. Ölçeğin diğer maddeleri tüm açılardan (kurama uygunluk, uygulanabilirlik, gözlenebilirlik) yeterli kapsam geçerlik değeri almıştır. Ölçeğin alt boyutlarına göre kapsam geçerlik indeksleri; kurama uygunluk açısından davranışçlıkta $.78(\mathrm{p}<.05)$, bilişsel anlayışta $.87(\mathrm{p}<.05)$ ve yapılandırmacılıkta $.85(\mathrm{p}<.05)$ 'dir. Maddede ifade edilen özelliğin uygulanabilirliği açısından KGİ incelendiğinde davranış̧̧ılıkta .84 (p<.05), bilişsel anlayışta $.88(\mathrm{p}<.05)$ ve yapılandırmacılıkta $.85(\mathrm{p}<.05)$ olarak hesaplanmıştır. Maddede ifade edilen özelliğin ortam ya da materyalde görülebilirliğini ifade eden gözlenebilirlik açısından da KGİ'leri davranışçılık için .89 $(\mathrm{p}<.05)$, bilişsel anlayış için .92 $(\mathrm{p}<.05)$ ve yapılandırmacılık için $.89(\mathrm{p}<.05)$ düzeyindedir. Ölçeğin genel KGI kurama uygunluk için $.81(\mathrm{p}<.05)$, uygulanabilirlik için $.85(\mathrm{p}<.05)$ ve gözlenebilirlik için $.88(\mathrm{p}<.05)$ 'dir. Ölçeğin hesaplanan KGI değerlerinin geçerliliği noktasından hareketle, sıkıntılı maddeler düzeltilerek ölçekte tutulmuştur. Nihai ölçek her öğrenme kuramına ilişkin 20 madde olmak üzere toplam 60 maddeden oluşmaktadır (Ek 2).

\section{Tartışma ve Sonuç}

Çalışmada, çevrimiçi öğretim ortamlarının ve materyallerinin öğrenme kuramları perspektifinden geliştirilmesini ve incelenmesini olanaklı kılacak, üzerinde uzlaşılmış bir ölçüt takımı oluşturulmuştur. Çalışmada elde edilen ölçütler takımının hem mevcut öğretim ortam ve materyallerinin incelenmesinde hem de yeni ortam ve materyallerinin geliştirilmesinde yararlı olacağı düşünülmektedir. Türkiye'deki öğretmenler tarafından üretilen öğretim materyallerinin ve ortamlarının paylaşıldığg bir platform olan EBA'nın, hem nitelikli materyallerle öğretim ortamlarını desteklemesi hem de öğretmenler tarafından geliştirilecek olan materyallere ve ortamlara rehberlik etmesi beklenir. Aksi durumda özellikle eğitim sistemi açısından düşünüldügünde ortaya çıkan ürünlerin belli bir kabul alanına düşmesi olanaklı olmayacak ya da üretilme süreçlerinde ve değerlendirilmelerinde kişisel ölçütler öne çıkacaktır. Bu çalışma kapsamında geliştirilen ölçek tutarlılığı sağlama ve niteliği geliştirmeye k1lavuzluk edebilir.

Bir öğrenme sürecinin, ortamının veya materyalinin nasıl tasarlanacağı öğrenme kuramlarının öğrenmenin ne olduğuna ve nasıl gerçekleştiğine dair açıklamalarına dayanmak durumundadır. Zira, yukarıda da belirttiğimiz gibi, bir öğretim ortam ya da süreci, öğreneni maruz bıraktığı süreçler ve sonuçları açısında kendisini ancak dayandığı öğrenme kuram ya da anlayışıyla açıklayabilir, meşrulaştırabilir. Seels ve Glasgow (1990: 3-4) bu gerekliliği, “Öğretim tasarımı, nitelikli öğrenmeler gerçekleştirmeyi sağlayacak öğretimsel düzeneklerin, öğrenme ve öğretme kuramlarından yararlanılarak sistematik olarak oluşturulması sürecidir. Öğretim rastlantılara bırakılamaz, iyi düzenlenmiş süreçler gerektirir ve gözlenebilir çıktılar vermelidir." olarak açıklamıştır. "Öğretim tasarımcılarının, öğreticilerin yükümlülüğü ise, öğrenme ve öğretme ilkelerini, öğretim materyalleri ve etkinlikleri için uygulamalara dönüştürmektir”" (Smith ve Ragan, 1993: 12).

Öğrenme kuramlarının öğretimsel süreçlere yansıtılması, öğretim uygulamalarına dönüştürülmesi oldukça zorlayıcı çabalar gerektirir. Bunun için öncelikle kuramların öğrenme açıklamalarının ve uygulamalarının ayrımının yapılması gereklidir (Hung, 2001). Temele alınan öğrenme kuramına göre öğretim hedefleri nasıl ve ne zaman belirlenecek, içerik nasıl oluşturulacak, öğretim etkinlikleri nasıl düzenlenecek, öğrenmeler nasıl ve ne zaman sınanacaktır? Bu büyük soru doğrultusunda üretilen cevapların, bir çevrimiçi öğrenme ortam ya da materyalindeki bütünlüklü görünümünü belirlemekse ikinci bir güçlük noktası olabilir. Bu çalışma, bu güçlüklerin aşılması ve öğrenme kuramı öğretimsel uygulama uyumluluğunun sağlanması için öğretim düzenleyicilere destek vermek üzere gerçekleştirilmiştir. Kuramların öğretim materyal ya da ortamlarına yansıması konusunda, uygulamalar üzerinden sağlanacak bir açıklık hem yeni materyallerin geliştirilmesi hem de mevcutların iyileştirilmesi noktasında yarar sağlayabilir. 


\section{References}

Akgün, M., \& Akgün, İ.H. (2011). Dünyada ve Türkiye'de bilgisayar destekli öğretimin tarihi gelişimi. [Historical development of computer assisted instruction in the world and Turkey], 2nd International Conference on New Trends in Education and Their Implications, 27-29 Aralık 2011, Antalya-Türkiye.

Aliakbari, F., Parvin, N., Heidari, M., \& Haghani, F. (2015). Learning theories application in nursing education. Journal of Education and Health Promotion, 4(2), 3-11. doi: 10.4103/2277-9531.151867

Alzaghoul, A. F. (2012). The implication of the learning theories on implementing e-learning courses. The Research Bulletin of Jordan ACM, 11(11), 27-30.

Aqda, M. F., Hamidi, F., \& Ghorbandordinejad, F. (2011). The impact of constructivist and cognitive distance instructional design on the learner's creativity. Procedia Computer Science, 3, 260-265. doi:10.1016/j.procs.2010.12.044

Aydın. C.H. (2000). Öğrenme ve öğretme kuramlarının eğitim iletişimine katkısı. [Contribution of learning and teaching theories to educational communication] Kurgu Dergisi, 17, 183-197.

Bay, E., Kaya, H. İ., \& Gündoğdu, K. (2010). Demokratik yapılandırmacı öğrenme ortamı ölçeği geliştirilmesi. [Developing a democratic constructivist learning environment scale] E-Journal of New World Science Academy Educational Sciences, 5(2), 646-664.

Boghossian, P.(2006). Behaviorism, constructivism, and socratic pedagogy. Educational Philosophy and Theory, 38(6), 713-722.

Bognar, B. (2016). Theoretical backgrounds of e-learning. Hrvatski časopis za odgoj i obrazovanje, 18(1), 225256.

Burton, J. K., Moore, D. M., \& Magliaro, S. G. (2004). Behaviorism and instructional technology. In D.H. Jonassen (Ed.) Handbook of Research For Educational Communications and Technology, (2nd ed. pp. 3-36). Mahwah, NJ: Lawrence Erlbaum.

Cennamo, K. S., Abell, S.K., \& Chung, M-L. (1996). A" Layers of Negotiation" Model for Designing Constructivist Learning Materials. Educational Technology, 36(4), 39-48.

Clemons, S. A. (2006). Constructivism pedagogy drives redevelopment of CAD course: a case study: Rather than feeding information to the student through direct instruction, the teacher is maintaining the role of facilitator in the learning process. The Technology Teacher, 65(5), 19-22.

Cognitive Approaches to Learning, (2008). Definition. http://www.sparkplug9.com/etec512/sparkplug9.com/etec512/2008/09/28/definition/index.html adresinden 08.05.2016 tarihinde erişilmiştir.

Cunningham, D., \& Duffy, T. (1996). Constructivism: Implications for the design and delivery of instruction. Handbook of research for educational communications and technology, 170-198.

Deubel, P. (2003). An investigation of behaviorist and cognitive approaches to instructional multimedia design. Journal of educational multimedia and hypermedia, 12(1), 63-90.

Dobozy, E., \& Dalziel, J. (2016). Transdisciplinary pedagogical templates and their potential for adaptive reuse. Journal of Interactive Media in Education, 8(1), 1-11. doi: http://dx.doi.org/10.5334/jime.402

Edgar, D. W. (2012). Learning Theories and Historical Events Affecting Instructional Design in Education. Sage Open, 2(4), 1-9.

Erdem, M. \& Ekici, M. (2016). Yapılandırmacı Değerlendirme ve Çevrimiçi Öğrenme Ortamları. A. İşman, H. F., Odabaşı, B. Akkoyunlu (Ed.) Eğitim Teknolojileri Okumaları 2016. (32. Bölüm s: 575-592). TOJET-The Turkish Online Journal of Educational Technology.

Ertmer, P. A., \& Newby, T. J. (2013). Behaviorism, cognitivism, constructivism: Comparing critical features from an instructional design perspective. Performance Improvement Quarterly, 26(2), 43-71. 
Ertmer, P.A., \& Newby, T.J. (2016). Learning theory and technology. In The Wiley Handbook of Learning Technology (Eds. N. Rushby \& D.W. Surry)(p. 58-76). Chichester: John Wiley \& Sons.

Gagne, R. M. (1965). The analysis of instructional objectives for the design of instruction. Teaching machines and programmed learning II: Data and directions, 21-65.

Ghani, N. A., Hamim, N., \& Ishak, N. I. (2006). Applying mastery learning model in developing e-tuition science for primary school students. Malaysian Online Journal of Instructional Technology, 3(2), 43-49.

Hassan, O. A.(2011). Learning theories and assessment methodologies-an engineering educational perspective. European Journal of Engineering Education, 36(4), 327-339.

Hean, S., Craddock, D., \& O’Halloran, C. (2009). Learning theories and interprofessional education: A user's guide. Learning in Health and Social Care, 8(4), 250-262. doi: 10.1111/j.1473-6861.2009.00227.x.

Hung, D. (2001). Theories of learning and computer-mediated instructional technologies. Educational Media International, 38(4), 281-287.

Johnson, G. M. (2014). The ecology of interactive learning environments: Situating traditional theory. Interactive Learning Environments, 22(3), 298-308. doi: http://dx.doi.org/10.1080/10494820.2011.649768

Jonassen, D. H. (1994). Thinking technology: Toward a constructivist design model. Educational Technology, 34(4), 34-37.

Kanjug, I., \& Chaijaroen, S. (2012). The design of web-based learning environments enhancing mental model construction. Procedia - Social and Behavioral Sciences, 46, 3134-3140.

Karagiorgi, Y., \& Symeou, L. (2005). Translating constructivism into instructional design: Potential and limitations. Educational Technology ve Society, 8(1), 17-27.

Kay, D., ve Kibble, J. (2016). Learning theories 101: Application to everyday teaching and scholarship. Advances in Physiology Education, 40, 17-25.

Khalil, M.K., \& Elkhider, I.A. (2016). Applying learning theories and instructional design models for effective instruction. Advances in Psysiology Education, 40, 147-156. doi: 10.1152/advan.00138.2015.

Krause, K. L., Bochner, S., \& Duchesne, S. (2003). Educational psychology for learning and teaching. Victoria: Thompson.

Lainema, T., \& Makkonen, P. (2003). Applying constructivist approach to educational business games: Case REALGAME. Simulation ve gaming, 34(1), 131-149.

Lawshe, C.H. (1975). A quantitative approach to content validity. Personnel Psychology, 28(4), 563-575.

McKenna, P., \& Laycock, B. (2004). Constructivist or instructivist: Pedagogical concepts practically applied to a computer learning environment. ACM SIGCSE Bulletin, 36(3), 166-170.

Mechlova, E., \& Malcik, M. (2012, November). ICT in changes of learning theories. 2012 IEEE 10th International Conference on Emerging eLearning Technologies ve Applications (ICETA), 253-262.

Mergel, B. (1998). Instructional design ve learning theory. http://etad.usask.ca/802papers/mergel/brenda.htm adresinden 1 Mayıs 2017 tarihinde erişilmiştir.

Mishra, S.(2002). A design framework for online learning environments. British Journal of Educational Technology, 33(4), 493-496.

Mödritscher, F. (2006). E-learning theories in practice: A comparison of three methods. Journal of Universal Science and Technology of Learning, 28, 3-18.

Özbek, R. (2005). Eğitim programlarının bireyselleştirilmesinin sebepleri. Elektronik Sosyal Bilimler Dergisi, 3(11), 66-83.

Reed, C. S. (2012). Learning theories applied to teaching technology: constructivism versus behavioral theory for instructing multimedia software programs. Dissertation of Doctoral of Philosophy. Capella University, Harold Abel School of Social and Behavioral Sciences, Minneapolis. 
Reigeluth, C. M. (1999). What is instructional-design theory and how is it changing. Instructional-design theories and models: A new paradigm of instructional theory, 2, 5-29.

Romero, V.L., Berger, D.E., Healy, M.R., \& Aberson, C.L. (2000). Using cognitive learning yheory to design effective on-line statistics tutorials. Behavior Research Methods, Instruments, \& Computers, 32(2), $246-249$.

Schunk, D. H.(2014). Öğrenme teorileri: Ĕ̆itimsel bir bakışla (M. Şahin, Çev.). Ankara: Nobel Yayıncılık.

Seels, B., \& Glasgow, Z. (1990). Exercises in instructional design. Columbus: Merrill Publishing Company..

Semerci, Ç.(2001). Oluşturmacılık kuramına göre ölçme ve değerlendirme. [Measurement and evaluation according to the theory of constructivism] Kuram ve Uygulamada Eğitim Bilimleri, 1(2), 429-440.

Sen, A. (2011). Examining the evolution of instructional technology from the perspective of its foundational literature. Doctoral Dissertation. Northern Illinois University, Department of Educational Technology, Research and Assesment. DeKalb, Illinois, U.S.

Skinner, B. F.(1986). Programmed instruction revisited. Phi Delta Kappan, 68(2), 10-103.

Smith, P.L., \& Ragan, T.J. (1993). Instructional Design. New York: Macmillan.

Tamim, S. R., \& Grant, M. M. (2016). Exploring Instructional Strategies and Learning Theoretical Foundations of eHealth and mHealth Education Interventions. Health promotion practice, 1524839916646715.

Tennyson, R.D. (2010). Historical reflection on learning theories and instructional design. Contemporary Educational Technology, 1(1), 1-16.

Tinker, R. (1997). Thinking About Science. (Elektronik Sürüm).Concord: The Concord Consortium Educational Technology Lab, M.A.

Vural, M. (2005). İlköğretim okulu ders programları ve öğretim kılavuzları (1-5. sinıflar). [Primary school curriculum and instruction manuals] Erzurum: Yakutiye Yayınc1lı.

Wong, B. S., \& Kang, L. (2012). Mastery learning in the context of university education. The Journal of the NUS Teaching Academy, 2, 206-22.

Wu, W.-H.,Hsiao, H.-C., Wu, P.-L., Lin, C.-H., \& Huang, S.-H. (2012). Investigating the learning-theory foundations of game-based learning: A meta-analysis. Journal of Computer Assisted Learning, 28, 265-279.

Yaşar, Ş.(1989). Yabancı dil öğretiminde çağdaş bir eğitim teknolojisi yaklaşımı:Programlı öğretim. [A contemporary educational technology approach in foreign language teaching] Eğitim ve Bilim, 13(74), 19-26.

Zhou, L. (2004). Influence of learning theories on research about computer technology applications in elementary classrooms. Doctoral Dissertation. Indiana University, The School of Graduate Studies and Research Professional Studies in Education, Pennsylvania, U.S. 
Ek -1.

\begin{tabular}{|c|c|c|c|c|c|c|}
\hline \multirow[b]{2}{*}{ CRITERIA } & \multicolumn{2}{|c|}{$\begin{array}{l}\text { Compliance with } \\
\text { Theory }\end{array}$} & \multicolumn{2}{|c|}{ Feasibility } & \multicolumn{2}{|c|}{ Observability } \\
\hline & $\mathbf{N}$ & CVR & $\mathbf{N}$ & CVR & $\mathbf{N}$ & CVR \\
\hline BEHAVIOURIST INSTRUCTIONAL PRACTICES & 26.00 & $1.00 *$ & 24.00 & $0.85^{*}$ & 23.00 & $0.77 *$ \\
\hline 1. Learning outputs to be obtained at the end of the process are clearly expressed. & 22.00 & $0.69^{*}$ & 17.00 & 0.31 & 21.00 & $0.62 *$ \\
\hline 2. Process is initiated by a specific context-free information. & 23.00 & $0.77^{*}$ & 23.00 & $0.77^{*}$ & 24.00 & $0.85^{*}$ \\
\hline 3. All individuals are provided with the same information in the same manner. & 24.00 & $0.85^{*}$ & 22.00 & $0.69^{*}$ & 23.00 & $0.77 *$ \\
\hline 4. Progress is designed to be "dependent" on the reactions of the students. & 16.00 & 0.23 & 20.00 & $0.54^{*}$ & 24.00 & $0.85^{*}$ \\
\hline 5. Education is largely built on the question (stimulant)-answer (reaction) relation. & 21.00 & $0.62 *$ & 24.00 & $0.85^{*}$ & 23.00 & $0.77 *$ \\
\hline 6. Questions test the information provided. & 21.00 & $0.62 *$ & 23.00 & $0.77^{*}$ & 24.00 & $0.85^{*}$ \\
\hline 7. Questions with a single correct answer and few distracters are used. & 21.00 & $0.62^{*}$ & 25.00 & $0.92 *$ & 25.00 & $0.92 *$ \\
\hline 8. Questions are repeated without any changes until the student finds the correct answer. & 19.00 & $0.46^{*}$ & 24.00 & $0.85^{*}$ & 24.00 & $0.85^{*}$ \\
\hline $\begin{array}{l}\text { 9. The student is not expected to make an explanation for the answer given or choice } \\
\text { made in the questions. }\end{array}$ & 25.00 & $0.92 *$ & 25.00 & $0.92 *$ & 26.00 & $1.00^{*}$ \\
\hline $\begin{array}{l}\text { 10. Tasks are designed in a linear order and passing to the next task is not allowed } \\
\text { without the completion of the previous ones. }\end{array}$ & 20.00 & $0.54 *$ & 23.00 & $0.77 *$ & 25.00 & $0.92 *$ \\
\hline 11. Activities are designed in line with the principle of self-study of the student. & 22.00 & $0.69^{*}$ & 22.00 & $0.69^{*}$ & 25.00 & $0.92 *$ \\
\hline $\begin{array}{l}\text { 12. Activities are designed in a manner which enables the students to progress in their } \\
\text { individual speeds. }\end{array}$ & 26.00 & $1.00 *$ & 26.00 & $1.00 *$ & 26.00 & $1.00^{*}$ \\
\hline 13. Numerous mechanical repetitions are made for permanent learning. & 25.00 & $0.92 *$ & 25.00 & $0.92^{*}$ & 25.00 & $0.92 *$ \\
\hline 14. Rewards/punishments are given to the students for their answers. & 25.00 & $0.92 *$ & 26.00 & $1.00^{*}$ & 26.00 & $1.00^{*}$ \\
\hline $\begin{array}{l}\text { 15. Conformity to constant features such as age and sex is respected in the selection of } \\
\text { the given reward or punishment. }\end{array}$ & 25.00 & $0.92 *$ & 26.00 & $1.00^{*}$ & 26.00 & $1.00^{*}$ \\
\hline 16. Content is offered in the form of small meaningful sub-units. & 20.00 & $0.54 *$ & 21.00 & $0.62 *$ & 23.00 & $0.77 *$ \\
\hline 17. Assessment is integrated with the learning process. & 25.00 & $0.92 *$ & 26.00 & $1.00^{*}$ & 26.00 & $1.00^{*}$ \\
\hline 18. All students are assessed with the same criteria. & 26.00 & $1.00^{*}$ & 25.00 & $0.92 *$ & 25.00 & $0.92 *$ \\
\hline 19. Assessment is system-centred. & 24.00 & $0.85^{*}$ & 24.00 & $0.85^{*}$ & 24.00 & $0.85^{*}$ \\
\hline $\begin{array}{l}\text { 20. In the assessment sections designed independently from the education, assessment } \\
\text { questions are same or very similar with the ones used in education. }\end{array}$ & 26.00 & $1.00 *$ & 24.00 & $0.85^{*}$ & 23.00 & $0.77 *$ \\
\hline FACTOR CVI & \multicolumn{2}{|c|}{$0.79 *$} & \multicolumn{2}{|c|}{$0.85^{*}$} & \multicolumn{2}{|c|}{$0.89 *$} \\
\hline \multicolumn{7}{|l|}{ COGNITIVE INSTRUCTIONAL PRACTICES } \\
\hline 21. Process is initiated with an attention-grabbing stimulant. & 26.00 & $1.00 *$ & 26.00 & $1.00 *$ & 26.00 & $1.00 *$ \\
\hline $\begin{array}{l}\text { 22. Learning outputs that the students are expected to gain at the end of the process are } \\
\text { clearly expressed. }\end{array}$ & 24.00 & $0.85^{*}$ & 25.00 & $0.92 *$ & 26.00 & $1.00^{*}$ \\
\hline $\begin{array}{l}\text { 23. Activities aiming at recalling the previous learnings are held at the beginning of the } \\
\text { process. }\end{array}$ & 26.00 & $1.00^{*}$ & 26.00 & $1.00^{*}$ & 25.00 & $0.92 *$ \\
\hline
\end{tabular}


Özer-Şanal\&Akçay\&Çiçek-Tutulmaz\&Erdem

\begin{tabular}{|c|c|c|c|c|c|c|}
\hline $\begin{array}{l}\text { 24. Tools/tests aiming at determining the features of the students (previous knowledge, } \\
\text { learning styles etc.) are offered. }\end{array}$ & 26.00 & $1.00 *$ & 26.00 & $1.00^{*}$ & 22.00 & $0.69 *$ \\
\hline 25. Process is independent from the student reactions. & 15.00 & 0.15 & 21.00 & $0.62 *$ & 24.00 & $0.85^{*}$ \\
\hline $\begin{array}{l}\text { 26. Content is designed in a meaningful manner and relations among the information are } \\
\text { emphasized. }\end{array}$ & 25.00 & $0.92 *$ & 24.00 & $0.85^{*}$ & 26.00 & $1.00 *$ \\
\hline 27. Content contains questions enabling association with the daily life. & 26.00 & $1.00 *$ & 26.00 & $1.00 *$ & 24.00 & $0.85 *$ \\
\hline $\begin{array}{l}\text { 28. Questions with a single correct answer and many distracters or open-ended questions } \\
\text { are included. }\end{array}$ & 23.00 & $0.77 *$ & 24.00 & $0.85^{*}$ & 26.00 & $1.00 *$ \\
\hline 29. Questions are offered in different forms in the repetitive tests for the learning. & 25.00 & $0.92 *$ & 26.00 & $1.00 *$ & 23.00 & $0.77 *$ \\
\hline 30. Design allows the student to progress and move as wished during the process. & 24.00 & $0.85^{*}$ & 23.00 & $0.77 *$ & 23.00 & $0.77 *$ \\
\hline $\begin{array}{l}\text { 31. The pace of the process is designed by taking the time that the student might need for } \\
\text { processing and coding the information into consideration. }\end{array}$ & 25.00 & $0.92 *$ & 25.00 & $0.92 *$ & 25.00 & $0.92 *$ \\
\hline $\begin{array}{l}\text { 32. Design allows the students to adjust their progresses in line with their own learning } \\
\text { speeds. }\end{array}$ & 24.00 & $0.85^{*}$ & 25.00 & $0.92 *$ & 26.00 & $1.00 *$ \\
\hline 33. Techniques supporting the permanence of learning are implemented or recommended. & 26.00 & $1.00 *$ & 26.00 & $1.00^{*}$ & 26.00 & $1.00 *$ \\
\hline $\begin{array}{l}\text { 34. Incentive explanations as to where the information learned in the environment can be } \\
\text { used are included. }\end{array}$ & 26.00 & $1.00 *$ & 26.00 & $1.00^{*}$ & 26.00 & $1.00 *$ \\
\hline $\begin{array}{l}\text { 35. The opportunity is provided for repetition with related but different examples for } \\
\text { permanent learning. }\end{array}$ & 26.00 & $1.00 *$ & 26.00 & $1.00^{*}$ & 26.00 & $1.00 *$ \\
\hline $\begin{array}{l}\text { 36. Different materials or activities are used in line with the learning features of the } \\
\text { students (learning preference or style). }\end{array}$ & 21.00 & $0.62 *$ & 21.00 & $0.62 *$ & 21.00 & $0.62 *$ \\
\hline $\begin{array}{l}\text { 37. Individual characteristics of the students are determined and students are } \\
\text { recommended to prefer the materials or activities suitable for their characteristics. }\end{array}$ & 24.00 & $0.85^{*}$ & 24.00 & $0.85^{*}$ & 24.00 & $0.85 *$ \\
\hline $\begin{array}{l}\text { 38. Explanations facilitating the association of the new information with the previous } \\
\text { knowledge are used. }\end{array}$ & 25.00 & $0.92 *$ & 26.00 & $1.00^{*}$ & 26.00 & $1.00 *$ \\
\hline $\begin{array}{l}\text { 39. Assessment is not integrated with the learning process, and a separate assessment } \\
\text { activity is arranged. }\end{array}$ & 19.00 & $0.46^{*}$ & 19.00 & $0.46^{*}$ & 20.00 & $0.54 *$ \\
\hline $\begin{array}{l}\text { 40. Students are assessed with the same criteria in terms of their levels of attaining the } \\
\text { objectives. }\end{array}$ & 22.00 & $0.69 *$ & 23.00 & $0.77 *$ & 24.00 & $0.85 *$ \\
\hline FACTOR CVI & \multicolumn{2}{|c|}{$0.91 *$} & \multicolumn{2}{|c|}{$0.93 *$} & \multicolumn{2}{|c|}{$0.92 *$} \\
\hline \multicolumn{7}{|l|}{ CONSTRUCTIVIST INSTRUCTIONAL PRACTICES } \\
\hline 41. Process enables the student to follow different paths depending on the preferences. & 25.00 & $0.92 *$ & 24.00 & $0.85^{*}$ & 24.00 & $0.85^{*}$ \\
\hline $\begin{array}{l}\text { 42. In the process, topics or problem areas to be elaborated and tasks to be carried out are } \\
\text { given as options. }\end{array}$ & 22.00 & $0.69^{*}$ & 25.00 & $0.92 *$ & 25.00 & $0.92 *$ \\
\hline 43. Process is initiated with a question or problem given together with the context. & 26.00 & $1.00 *$ & 26.00 & $1.00 *$ & 26.00 & $1.00 *$ \\
\hline $\begin{array}{l}\text { 44. Cases and real life tasks are presented/ recommended to emphasize student-student } \\
\text { interaction. }\end{array}$ & 25.00 & $0.92 *$ & 23.00 & $0.77 *$ & 23.00 & $0.77 *$ \\
\hline $\begin{array}{l}\text { 45. As a principle, education is carried out in a deductive manner with an emphasis on the } \\
\text { meaning relation between the whole and the part. }\end{array}$ & 18.00 & $0.38 *$ & 23.00 & $0.77 *$ & 24.00 & $0.85 *$ \\
\hline $\begin{array}{l}\text { 46. Education is task-based and designed in a manner to include tasks which require } \\
\text { going beyond the environment or material. }\end{array}$ & 22.00 & $0.69 *$ & 24.00 & $0.85^{*}$ & 25.00 & $0.92 *$ \\
\hline $\begin{array}{l}\text { 47. Solutions of the questions or problems are given or asked under identified validity } \\
\text { conditions (context). }\end{array}$ & 19.00 & $0.46^{*}$ & 20.00 & $0.54 *$ & 21.00 & $0.62 *$ \\
\hline
\end{tabular}


Öğrenme Kuramlarının Uygulanması

\begin{tabular}{|c|c|c|c|c|c|c|}
\hline 48. Tools facilitating the interaction of the student with the others are offered. & 26.00 & $1.00 *$ & 26.00 & $1.00^{*}$ & 26.00 & $1.00 *$ \\
\hline 49. Incentives embedded in the context are emphasized and highlighted. & 26.00 & $1.00 *$ & 24.00 & $0.85^{*}$ & 24.00 & $0.85^{*}$ \\
\hline 50. Different activities which may satisfy the preferences of the students are offered. & 25.00 & $0.92 *$ & 24.00 & $0.85^{*}$ & 24.00 & $0.85^{*}$ \\
\hline $\begin{array}{l}\text { 51. In the case of a content offered in different forms, the selection of the form is left to } \\
\text { the discretion of the student. }\end{array}$ & 25.00 & $0.92 *$ & 25.00 & $0.92 *$ & 26.00 & $1.00 *$ \\
\hline 52. Environment provides the student with real life experiences. & 25.00 & $0.92 *$ & 25.00 & $0.92 *$ & 26.00 & $1.00 *$ \\
\hline 53. On a topic, different and sometimes contradictory information are given together. & 24.00 & $0.85 *$ & 24.00 & $0.85^{*}$ & 25.00 & $0.92 *$ \\
\hline 54. Content is offered embedded in a situation, event or story or in the form of a problem. & 25.00 & $0.92 *$ & 25.00 & $0.92 *$ & 25.00 & $0.92 *$ \\
\hline 55. Assessment is not designed as a separate activity; it is integrated with learning. & 26.00 & $1.00 *$ & 25.00 & $0.92 *$ & 26.00 & $1.00 *$ \\
\hline $\begin{array}{l}\text { 56. In order to obtain data for self-assessment, reflective thinking questions requiring the } \\
\text { student to answer by considering the entirety of his learning process are directed. }\end{array}$ & 25.00 & $0.92 *$ & 25.00 & $0.92 *$ & 26.00 & $1.00 *$ \\
\hline $\begin{array}{l}\text { 57. Assessment is designed in a manner to use the opinions of the student (self- } \\
\text { assessment), peers and teacher (system) together. }\end{array}$ & 18.00 & $0.89 *$ & 23.00 & $0.77 *$ & 24.00 & $0.85^{*}$ \\
\hline $\begin{array}{l}\text { 58. Design allows the assessment of all performance data in the process along with the } \\
\text { targeted learnings. }\end{array}$ & 18.00 & $0.89 *$ & 23.00 & $0.77 *$ & 24.00 & $0.85^{*}$ \\
\hline $\begin{array}{l}\text { 59. Tools enabling the determination of different performance levels are used in the } \\
\text { process. }\end{array}$ & 24.00 & $0.85^{*}$ & 24.00 & $0.85^{*}$ & 24.00 & $0.85^{*}$ \\
\hline $\begin{array}{l}\text { 60. Students are allowed to choose the performance expression tool based on their } \\
\text { preferences. }\end{array}$ & 23.00 & $0.77 *$ & 22.00 & $0.69^{*}$ & 24.00 & $0.85^{*}$ \\
\hline FACTOR CVI & \multicolumn{2}{|c|}{$0.85^{*}$} & \multicolumn{2}{|c|}{$0.85 *$} & \multicolumn{2}{|c|}{$0.89 *$} \\
\hline
\end{tabular}

Ek - 2 .

\begin{tabular}{|c|c|c|c|c|c|c|}
\hline \multirow[b]{2}{*}{ ÖLÇÜTLER } & \multicolumn{2}{|c|}{$\begin{array}{c}\text { Kurama } \\
\text { uygunluk }\end{array}$} & \multicolumn{2}{|c|}{ Uygulanabilirlik } & \multicolumn{2}{|c|}{ Gözlenebilirlik } \\
\hline & $\mathbf{N}$ & KGO & $\mathbf{N}$ & KGO & $\mathbf{N}$ & KGO \\
\hline DAVRANIŞÇI ÖĞRETIMSEL DÜZENLEMELER & 26.00 & $1.00 *$ & 24.00 & $0.85^{*}$ & 23.00 & $0.77 *$ \\
\hline $\begin{array}{l}\text { 1. Öncelikle, süreç sonunda elde edilecek öğrenme çıktıları, açık ve net bir şekilde ifade } \\
\text { edilmiştir. }\end{array}$ & 22.00 & $0.69 *$ & 17.00 & 0.31 & 21.00 & $0.62 *$ \\
\hline 2. Süreç, bağlamdan bağımsız spesifik bir bilgiyle başlatılmıştır. & 23.00 & $0.77 *$ & 23.00 & $0.77 *$ & 24.00 & $0.85^{*}$ \\
\hline 3. Tüm bireylere aynı bilgiler aynı yollarla sunulmuştur. & 24.00 & $0.85^{*}$ & 22.00 & $0.69 *$ & 23.00 & $0.77^{*}$ \\
\hline $\begin{array}{l}\text { 4. İlerleme, öğrencilerin tepkilerine "bağımlı" olarak gerçekleşecek biçimde } \\
\text { tasarlanmıştır. }\end{array}$ & 16.00 & 0.23 & 20.00 & $0.54 *$ & 24.00 & $0.85^{*}$ \\
\hline 5. Öğretim, büyük ölçüde soru (uyarıc1)-cevap (tepki) ikilisi üzerine kurulmuştur. & 21.00 & $0.62 *$ & 24.00 & $0.85^{*}$ & 23.00 & $0.77 *$ \\
\hline 6. Sorular, verilen bilgileri yoklayacak düzeyde hazırlanmıştır. & 21.00 & $0.62 *$ & 23.00 & $0.77 *$ & 24.00 & $0.85^{*}$ \\
\hline 7. Tek doğru cevabı olan, çeldirici sayısı az sorular sorulmuştur. & 21.00 & $0.62 *$ & 25.00 & $0.92 *$ & 25.00 & $0.92 *$ \\
\hline $\begin{array}{l}\text { 8. Sorular, öğrenci doğru cevabı buluncaya kadar, üzerinde değişiklik yapılmaksızın } \\
\text { tekrar edilmiştir. }\end{array}$ & 19.00 & $0.46^{*}$ & 24.00 & $0.85^{*}$ & 24.00 & $0.85^{*}$ \\
\hline $\begin{array}{l}\text { 9. Öğrencinin sorulara verdiği cevaba ya da yaptığı seçime açıklama getirmesi } \\
\text { beklenmemektedir. }\end{array}$ & 25.00 & $0.92 *$ & 25.00 & $0.92 *$ & 26.00 & $1.00 *$ \\
\hline
\end{tabular}


Özer-Şanal\&Akçay\&Çiçek-Tutulmaz\&Erdem

\begin{tabular}{|c|c|c|c|c|c|c|}
\hline $\begin{array}{l}\text { 10. Görevler doğrusal bir sıralamada tasarlanmış ve bir aşamadaki görev tamamlanmadan } \\
\text { diğerine geçmeye izin verilmemiştir. }\end{array}$ & 20.00 & $0.54 *$ & 23.00 & $0.77 *$ & 25.00 & $0.92 *$ \\
\hline 11. Etkinlikler öğrencinin tek başına çalışması esasına göre düzenlenmiştir. & 22.00 & $0.69 *$ & 22.00 & $0.69 *$ & 25.00 & $0.92 *$ \\
\hline $\begin{array}{l}\text { 12. Etkinlikler öğrencilerin kendi bireysel hızlarına göre ilerlemelerine olanak verecek } \\
\text { biçimde düzenlenmiştir. }\end{array}$ & 26.00 & $1.00 *$ & 26.00 & $1.00 *$ & 26.00 & $1.00^{*}$ \\
\hline 13. Kalıcı öğrenmeler için çok ve mekanik tekrara yer verilmiştir. & 25.00 & $0.92 *$ & 25.00 & $0.92 *$ & 25.00 & $0.92 *$ \\
\hline 14. Öğrencilere yanıtlarının ardından ödül/ceza verilmiştir. & 25.00 & $0.92 *$ & 26.00 & $1.00 *$ & 26.00 & $1.00^{*}$ \\
\hline $\begin{array}{l}\text { 15. Verilen ödül ya da cezanın seçiminde yaş, cinsiyet gibi değişmez özelliklere uygunluk } \\
\text { gözetilmiştir. }\end{array}$ & 25.00 & $0.92 *$ & 26.00 & $1.00 *$ & 26.00 & $1.00^{*}$ \\
\hline 16. İçerik küçük, anlamlı alt birimler halinde sunulmuştur. & 20.00 & $0.54 *$ & 21.00 & $0.62 *$ & 23.00 & $0.77 *$ \\
\hline 17. Değerlendirme öğrenme süreciyle bütünleşiktir. & 25.00 & $0.92 *$ & 26.00 & $1.00 *$ & 26.00 & $1.00^{*}$ \\
\hline 18. Tüm öğrenciler aynı ölçütlerle değerlendirilecek biçimde tasarlanmıştır. & 26.00 & $1.00^{*}$ & 25.00 & $0.92 *$ & 25.00 & $0.92 *$ \\
\hline 19. Değerlendirme sistem merkezlidir. & 24.00 & $0.85^{*}$ & 24.00 & $0.85 *$ & 24.00 & $0.85^{*}$ \\
\hline $\begin{array}{l}\text { 20. Öğretimden ayrı tasarlanmış değerlendirme bölümlerinde ölçme soruları, öğretimde } \\
\text { kullanılan soruların aynı ya da çok benzeridir. }\end{array}$ & 26.00 & $1.00 *$ & 24.00 & $0.85^{*}$ & 23.00 & $0.77^{*}$ \\
\hline FACTOR CVI & \multicolumn{2}{|c|}{$0.79 *$} & \multicolumn{2}{|c|}{$0.85^{*}$} & \multicolumn{2}{|c|}{$0.89 *$} \\
\hline BİLIŞSEL ÖĞRETİMSEL DÜZENLEMELER & $\mathbf{N}$ & KGO & $\mathbf{N}$ & KGO & $\mathbf{N}$ & KGO \\
\hline 21. Süreç dikkat çekici hale getirilmiş bir uyarıcıyla başlatılmıştır. & 26.00 & $1.00 *$ & 26.00 & $1.00 *$ & 26.00 & $1.00^{*}$ \\
\hline $\begin{array}{l}\text { 22. Süreç sonunda öğrencilerin kazanması beklenen öğrenme çıktıları açık ve net bir } \\
\text { şekilde belirtilmiştir. }\end{array}$ & 24.00 & $0.85^{*}$ & 25.00 & $0.92 *$ & 26.00 & $1.00^{*}$ \\
\hline 23. Sürecin başında önceki öğrenmeleri hatırlatıcı etkinliklere yer verilmiştir. & 26.00 & $1.00 *$ & 26.00 & $1.00 *$ & 25.00 & $0.92 *$ \\
\hline $\begin{array}{l}\text { 24. Öğrencilerin özelliklerini (ön bilgiler, öğrenme stilleri vb.) belirlemeye dönük } \\
\text { araçlar/testler sunulmuştur. }\end{array}$ & 26.00 & $1.00 *$ & 26.00 & $1.00 *$ & 22.00 & $0.69^{*}$ \\
\hline 25. Sürecin ilerlemesi öğrenci tepkilerinden bağımsızdır. & 15.00 & 0.15 & 21.00 & $0.62 *$ & 24.00 & $0.85^{*}$ \\
\hline 26. İçerik, anlamlı biçimde örgütlenmiş, bilgiler arasındaki ilişkiler vurgulanmıştır. & 25.00 & $0.92 *$ & 24.00 & $0.85 *$ & 26.00 & $1.00^{*}$ \\
\hline 27. İçerikte, günlük yaşamla ilişkilendirmeyi sağlayacak nitelikte sorulara yer verilmiştir. & 26.00 & $1.00 *$ & 26.00 & $1.00 *$ & 24.00 & $0.85^{*}$ \\
\hline 28. Çeldirici sayısı fazla ya da açık uçlu ve tek doğru cevaplı sorulara yer verilmiştir. & 23.00 & $0.77 *$ & 24.00 & $0.85^{*}$ & 26.00 & $1.00^{*}$ \\
\hline 29. Öğrenmelerin tekrarlı yoklamalarında sorular, farklı formlarda sunulmuştur. & 25.00 & $0.92 *$ & 26.00 & $1.00 *$ & 23.00 & $0.77 *$ \\
\hline $\begin{array}{l}\text { 30. Öğrencinin süreçte istediği gibi ilerlemesine, hareket etmesine izin veren bir tasarım } \\
\text { yapılmıştır. }\end{array}$ & 24.00 & $0.85^{*}$ & 23.00 & $0.77 *$ & 23.00 & $0.77 *$ \\
\hline $\begin{array}{l}\text { 31. Sürecin akış hızı, öğrencinin bilgiyi işleyip kodlaması için ihtiyaç duyabileceği zaman } \\
\text { dikkate alınarak tasarlanmıştır. }\end{array}$ & 25.00 & $0.92 *$ & 25.00 & $0.92 *$ & 25.00 & $0.92 *$ \\
\hline $\begin{array}{l}\text { 32. Öğrencilerin ilerleyişlerini kendi öğrenme hızlarına göre ayarlamalarına izin verecek } \\
\text { biçimde tasarlanmıştır. }\end{array}$ & 24.00 & $0.85^{*}$ & 25.00 & $0.92 *$ & 26.00 & $1.00^{*}$ \\
\hline 33. Öğrenmelerin kalıcılığını destekleyen teknikler uygulanmış ya da önerilmiştir. & 26.00 & $1.00 *$ & 26.00 & $1.00^{*}$ & 26.00 & $1.00^{*}$ \\
\hline $\begin{array}{l}\text { 34. Ortamda öğrenilenlerin nerelerde kullanılacağını ifade eden güdüleyici açıklamalara } \\
\text { yer verilmiştir. }\end{array}$ & 26.00 & $1.00 *$ & 26.00 & $1.00 *$ & 26.00 & $1.00^{*}$ \\
\hline 35. Kalıcı öğrenme için süreç içinde, ilişkili farklı örneklerle tekrar olanağı yaratılı & 26.00 & $1.00 *$ & 26.00 & $1.00 *$ & 26.00 & $1.00^{*}$ \\
\hline
\end{tabular}




\begin{tabular}{|c|c|c|c|c|c|c|}
\hline $\begin{array}{l}\text { 36. Öğrencilerin, öğrenme özelliklerine (öğrenme tercih ya da stili vb.) uygun farklı } \\
\text { materyal ya da etkinliklere yer verilmiştir. }\end{array}$ & 21.00 & $0.62 *$ & 21.00 & $0.62 *$ & 21.00 & $0.62 *$ \\
\hline $\begin{array}{l}\text { 37. Öğrencilere, bireysel özelliklerini belirleyip, özelliklerine uygun materyal ya da } \\
\text { etkinliklere yönelmeleri önerilmiştir. }\end{array}$ & 24.00 & $0.85^{*}$ & 24.00 & $0.85 *$ & 24.00 & $0.85^{*}$ \\
\hline $\begin{array}{l}\text { 38. Yeni bilgi ile önceki bilgiler arasında bağ kurmayı kolaylaştırıcı açıklamalara yer } \\
\text { verilmiştir. }\end{array}$ & 25.00 & $0.92 *$ & 26.00 & $1.00 *$ & 26.00 & $1.00^{*}$ \\
\hline $\begin{array}{l}\text { 39. Değerlendirme öğrenme süreciyle bütünleşik değildir, ayrı bir değerlendirme etkinliği } \\
\text { düzenlenmiştir. }\end{array}$ & 19.00 & $0.46^{*}$ & 19.00 & $0.46^{*}$ & 20.00 & $0.54 *$ \\
\hline $\begin{array}{l}\text { 40. Öğrenciler, aynı ölçütlerle ve hedeflere ulaşma düzeyleri bakımından } \\
\text { değerlendirilmiştir. }\end{array}$ & 22.00 & $0.69 *$ & 23.00 & $0.77 *$ & 24.00 & $0.85^{*}$ \\
\hline FACTOR CVI & \multicolumn{2}{|c|}{$0.91 *$} & \multicolumn{2}{|c|}{$0.93 *$} & \multicolumn{2}{|c|}{$0.92 *$} \\
\hline YAPILANDIRMACI ÖĞRETIMSSEL DÜZENLEMELER & $\mathbf{N}$ & KGO & $\mathbf{N}$ & KGO & $\mathbf{N}$ & KGO \\
\hline 41. Süreç öğrencinin tercihlerine göre farklı yollar izleyebileceği yapıda düzenlenmiştir. & 25.00 & $0.92 *$ & 24.00 & $0.85^{*}$ & 24.00 & $0.85^{*}$ \\
\hline $\begin{array}{l}\text { 42. Süreçte üzerinde durulacak konu ya da problem alanları, gerçekleştirilecek görevler, } \\
\text { seçenekli olarak belirtilmiştir. }\end{array}$ & 22.00 & $0.69 *$ & 25.00 & $0.92 *$ & 25.00 & $0.92 *$ \\
\hline 43. Süreç bağlamıyla birlikte verilmiş bir soru ya da problemle başlatılmıştır. & 26.00 & $1.00 *$ & 26.00 & $1.00 *$ & 26.00 & $1.00 *$ \\
\hline $\begin{array}{l}\text { 44. Öğrenci-öğrenci etkileşimine vurgu yapan örnek durumlar, ortam dışı, gerçek yaşam } \\
\text { görevleri sunulmuş/önerilmiştir. }\end{array}$ & 25.00 & $0.92 *$ & 23.00 & $0.77 *$ & 23.00 & $0.77^{*}$ \\
\hline $\begin{array}{l}\text { 45. Öğretim; ilke ile örnek, bütün ile parça arasındaki anlam ilişkisi vurgulanarak, } \\
\text { tümdengelim anlayışılla düzenlenmiştir. }\end{array}$ & 18.00 & $0.38 *$ & 23.00 & $0.77 *$ & 24.00 & $0.85^{*}$ \\
\hline $\begin{array}{l}\text { 46. Öğretim görev tabanlıdır ve ortamın ya da materyalin dışına çıkmayı gerektiren } \\
\text { görevler içerecek biçimde tasarlanmışır. }\end{array}$ & 22.00 & $0.69 *$ & 24.00 & $0.85^{*}$ & 25.00 & $0.92 *$ \\
\hline $\begin{array}{l}\text { 47. Soru ya da problemlerin çözümleri, tanımlanmış geçerlilik koşulları (bağlam) altında } \\
\text { verilmiş ya da istenmiştir. }\end{array}$ & 19.00 & $0.46^{*}$ & 20.00 & $0.54 *$ & 21.00 & $0.62 *$ \\
\hline 48. Öğrencinin diğerleriyle etkileşime girmesini kolaylaştırıcı araçlar sunulmuştur. & 26.00 & $1.00 *$ & 26.00 & $1.00^{*}$ & 26.00 & $1.00^{*}$ \\
\hline 49. Bağlama gömülü güdüleyiciler vurgulanarak öne çıkarılmıştır. & 26.00 & $1.00 *$ & 24.00 & $0.85^{*}$ & 24.00 & $0.85^{*}$ \\
\hline 50. Öğrencilerin tercihlerine cevap verebilecek farklı etkinlikler sunulmuştur. & 25.00 & $0.92 *$ & 24.00 & $0.85^{*}$ & 24.00 & $0.85^{*}$ \\
\hline $\begin{array}{l}\text { 51. Farklı formlarda sunulmuş içeriğin hangi formundan yararlanacağının seçimi } \\
\text { öğrenciye bırakılmıştır. }\end{array}$ & 25.00 & $0.92 *$ & 25.00 & $0.92 *$ & 26.00 & $1.00^{*}$ \\
\hline 52. Ortam öğrenciye gerçek yaşam deneyimi örnekleri sunmuştur. & 25.00 & $0.92 *$ & 25.00 & $0.92 *$ & 26.00 & $1.00^{*}$ \\
\hline 53. Aynı konuda farklı, bazen birbiriyle çelişen bilgiler birlikte sunulmuştur. & 24.00 & $0.85^{*}$ & 24.00 & $0.85^{*}$ & 25.00 & $0.92 *$ \\
\hline $\begin{array}{l}\text { 54. İçerik bir durum, olay ya da öyküye gömülü biçimde ya da bir problem formunda } \\
\text { sunulmuştur. }\end{array}$ & 25.00 & $0.92 *$ & 25.00 & $0.92 *$ & 25.00 & $0.92 *$ \\
\hline $\begin{array}{l}\text { 55. Değerlendirme, ayrı bir etkinlik olarak değil, öğrenmeyle bütünleşik olarak } \\
\text { tasarlanmıştır. }\end{array}$ & 26.00 & $1.00 *$ & 25.00 & $0.92 *$ & 26.00 & $1.00^{*}$ \\
\hline $\begin{array}{l}\text { 56. Öz değerlendirme için veri sağlamak üzere öğrenciye, kendi öğrenme sürecinin } \\
\text { tamamını dikkate alarak cevaplamasını gerektiren, yansıtıcı düşünme soruları } \\
\text { sorulmuştur. }\end{array}$ & 25.00 & $0.92 *$ & 25.00 & $0.92 *$ & 26.00 & $1.00^{*}$ \\
\hline $\begin{array}{l}\text { 57. Değerlendirme, bireyin kendisinin (öz değerlendirme), akranlarının ve öğretmenin } \\
\text { (sistemin) görüşleri birlikte kullanılacak şekilde tasarlanmıştır. }\end{array}$ & 18.00 & $0.89 *$ & 23.00 & $0.77 *$ & 24.00 & $0.85^{*}$ \\
\hline $\begin{array}{l}\text { 58. Sadece hedeflenen öğrenmeler değil, tüm süreçteki performans verilerini } \\
\text { değerlendirebilecek bir tasarım gerçekleştirilmiştir. }\end{array}$ & 18.00 & $0.89 *$ & 23.00 & $0.77 *$ & 24.00 & $0.85^{*}$ \\
\hline 59. Süreçte farklı performans düzeyi belirleme araçlarına yer verilmiştir. & 24.00 & $0.85^{*}$ & 24.00 & $0.85^{*}$ & 24.00 & $0.85^{*}$ \\
\hline
\end{tabular}


Özer-Şanal\&Akçay\&Çiçek-Tutulmaz\&Erdem

\begin{tabular}{|c|l|l|l|l|l|l|}
\hline 60. Öğrencinin tercihine uygun performans ifade aracını seçmesine olanak sağlanmıştır. & 23.00 & $0.77^{*}$ & 22.00 & $0.69^{*}$ & 24.00 & $0.85^{*}$ \\
\hline FACTOR CVI & \multicolumn{2}{|c|}{$\mathbf{0 . 8 5 *}^{*}$} & \multicolumn{2}{|c|}{$\mathbf{0 . 8 5 *}^{*}$} & \multicolumn{2}{|c|}{$\mathbf{0 . 8 9}^{*}$} \\
\hline
\end{tabular}

